\title{
Kritik Hukum Islam Atas Sanksi Pidana Pelaku Prostitusi dalam Peraturan Daerah
}

\author{
Nasrullah \& Aden Rosadi
}

\begin{abstract}
Islamic Criticism to the Criminal Sanctions of Prostitution Actors in Regional Regulations. This article examines the Regional regulations relating to prohibition of prostitution in Indonesia from the perspectives of Indonesian Law and Islamic Criminal Law. As this study reveals, a number of contradiction occurs between Regional Regulations with Criminal Code. Such contradictions can be found in a number of regional regulations prohibiting prostitution, such as : No. 5/2002 of Cirebon Regency; Regulation No. 6/2003 of Medan City; Regulation No. 2 /2004 of Palembang City, Regulation No. 13/2002 of South Sumatra Province, etc. The contradictions include the determination of the authorized officers to handle the matter, the rules in case of erroneous arrest, and the determination of sanctions. The Criminal Code sets aside sanctions for Commercial Sex Workers (CSWs) and users of CSWs. It only prohibits of facilitating the immoral acts by other parties.. In Islamic criminal Law, prostitution is considered as a crime whose perpetrators are equated with adulterers sanctioned with stoning or whip.
\end{abstract}

Keywords: prostitution in Islam, Commercial Sex Workers, criminal act and regional regulation

\begin{abstract}
Abstrak: Kritik Hukum Islam Atas Sanksi Pidana Pelaku Prostitusi dalam Peraturan Daerah. Artikel ini mengkaji tentang ketentuan dalam Peraturan Daerah terkait larangan prostitusi di Indonesia melalui perspektif Hukum Positif dan Hukum Pidana Islam. Seperti ditunjukkan oleh penelitian ini, sejumlah kontradiksi terjadi antara Peraturan Daerah dengan KUHP. Kontradiksi semacam itu dapat ditemukan di sejumlah peraturan daerah yang melarang pelacuran, seperti: No. 5/2002 di Kabupaten Cirebon; Peraturan No. 6/2003 di Kota Medan; Peraturan No. 2/2004 di Kota Palembang, Peraturan No. 13/2002 di Provinsi Sumatera Selatan, dan lain-lain. Kontradiksi tersebut meliputi penentuan petugas yang berwenang untuk menangani masalah ini, peraturan dalam kasus salah tangkap, dan penetapan sanksi. KUHP tidak memberi sanksi hukum bagi Pekerja Seks Komersial (PSK) dan pengguna PSK. Ia hanya melarang memfasilitasi tindakan tidak bermoral itu oleh pihak lain. Dalam Hukum Pidana Islam, pelacuran dianggap sebagai kejahatan, para pelakunya disamakan dengan pezina yang dikenai hukuman rajam atau cambuk.
\end{abstract}

Kata Kunci: prostitusi dalam hukum Islam, Pekerja Seks Komerisal, Peraturan Daerah

Fakultas Syariah dan Hukum Universitas Islam Negeri Sunan Gunung Djati Bandung Jl. A.H. Nasution No. 105, Cipadung, Cibiru, Cipadung, Cibiru, Kota Bandung, Jawa Barat 40614

E-mail: adenrosadi@yahoo.com dan nash_depag@yahoo.co.id 


\section{Pendahuluan}

Prostitusi adalah praktik yang di dalamnya terdapat wanita yang dipekerjakan oleh mucikari untuk memberikan jasa seks terhadap kaum laki-laki. Bahkan Edlund dan Korn (2002) menyebutkan bahwa prostitusi adalah sebuah pekerjaan yang dilakukan oleh wanita yang memiliki keterampilan rendah untuk mendapatkan gaji yang tinggi. Namun prostitusi sebagai tempat menularnya HIV/AIDS, dan terdapat 81,9\% penularan HIV/AIDS dilakukan dengan hubungan seks antara laki-laki dengan perempuan dengan cara yang tidak aman. ${ }^{1}$

Hukum Islam tidak menemukan nomenklatur secara implisit menyebut prostitusi. Prostitusi adalah penyediaan layanan seksual yang dilakukan oleh laki-laki atau perempuan untuk mendapatkan uang atau kepuasan. Apakah Unsur "layanan seksual" dalam definisi prostitusi mengandung arti hubungan badan antara laki-laki dan perempuan yang tidak terikat dengan hubungan pernikahan dapat dipersamakan dengan unsur zina dalam hukum Islam?. Inilah yang menjadi permasalahan yang perlu diperjelas status hukumnya, mengingat dalam hukum pidana nasional, istilah zina dengan prostitusi dibedakan deliknya. Hukuman pelaku zina terbagi dua, yaitu muhshan (sudah menikah) dihukum dengan cara dirajam ${ }^{2}$ dan ghair muhshan (belum menikah) dengan cara dijilid. ${ }^{3}$

Sanksi pidana yang diterapkan bagi pelaku prostitusi lebih implisit diatur di dalam peraturan-peraturan daerah. Jenis pidana di dalam peraturan daerah adalah pidana pelanggaran. Penetapan pidana pelanggaran di dalam hukum Islam lebih dijerat dengan jinâyah ta'zîr berupa kurungan dan atau denda. Bagaimana pidana yang menurut hukum Islam sebagai jinâyah hudûd namun hanya dijerat dengan jinâyah ta'zîr?

Upaya yang dilakukan pemerintah daerah untuk mencegah dan menanggulangi prostitusi dengan menjerat pelaku prostitusi dengan sanksi pidana pelanggaran menjadi permasalahan. Apakah penetapan sanksi

${ }^{1}$ Departemen Kesehatan RI, 2012.

${ }^{2}$ Abû Abdillah Muhammad bin Ismâ'îl al-Bukhârî, Sahîh al-Bukhârî, vol. juz 8 (Semarang: Toha Putra, tt); Abu al-Husain Muslim bin al-Hajjâj, Sahîh Muslim, vol. juz IV (Bayrût: Dâr Ihyầ al-âth al-'Arabî, tt).

${ }^{3}$ Q.s. al-Nûr [24] ayat 2. 
yang sangat ringan ini memiliki aspek penjera untuk tidak melakukan dan mengulangi tindak prostitusi. Dapatkah hukum pidana Islam dapat berperan untuk mencegah dan menanggulangi prostitusi secara efektif.

Kebijakan negara-negara di dunia tentang prostitusi secara garis besar terdiri dari 4 (empat) jenis. Pertama, legalisasi yakni melegalkan praktik prostitusi. Kedua, kriminalisasi yakni mengkriminalkan pelaku prostitusi. Ketiga, dekriminalisasi yakni upaya untuk tidak mengkriminalkan pelaku prostitusi. Keempat, abolisi, yakni upaya untuk menghapus sampai ke akarakarnya praktik prostusi, karena prostitusi dianggap sebagai perbudakan. Indonesia termasuk negara yang menerapkan kebijakan kriminalisasi. Pelaku prostitusi dianggap sebagai tindakan kriminal dan harus dikenai sanksi pidana. Namun pada praktiknya prostitusi tidak pernah habis dan malah tumbuh subur. Perlukah merubah kebijakan dari kriminalisasi menuju abolisi?.

Peraturan daerah tentang larangan prostitusi menetapkan sanksi pidana dengan sanksi berupa denda dan kurungan. Penetapan sanksi tidak boleh melebihi batas yang diatur di dalam Pasal 15 ayat (2) Undang-Undang No. 12 Tahun 2011 tentang Pembentukan Peraturan Perundang-undangan yang mengatur bahwa peraturan daerah tidak boleh mendenda melebihi Rp. 50.000.000,- (lima puluh juta rupiah), dan tidak boleh mengurung lebih dari 6 (enam bulan). Dalam pidana Islam, prostitusi termasuk pada jinâyah hudûd yang dipersamakan dengan perzinaan dengan hukuman rajam atau jilid. Sedangkan dalam hukum positif prostitusi diatur di dalam Kitab Undang-Undang Hukum Pidana (KUHP). KUHP melarang pihak yang memfasilitasi tindak asusila oleh pihak lain sebagai mata pencaharian (Pasal 296), perdagangan perempuan (Pasal 297), penggelandangan (Pasal 505) dan hidup dari penghasilan seorang pekerja seks perempuan (Pasal 506). Tidak ditemukan pasal dalam KUHP yang menjerat pekerja seksual komersial (PSK) dan pengguna jasa PSK.

Berdasarkan uraian di atas maka ditemukan kesenjangan antara peraturan daerah terkait prostitusi yang memuat sanksi pidana dengan hukum pidana Islam. Hal inilah yang menjadi permasalahan bagaimana tinjauan hukum pidana Islam terhadap peraturan daerah terkait larangan prostitusi di Indonesia. Maka untuk menjawab permasalahan tersebut 
dirumuskan beberapa pertanyaan. Pertama, bagaimana kedudukan peraturan daerah terkait larangan prostitusi di Indonesia dalam tata urutan peraturan perundang-undangan?. Kedua, apakah sanksi pidana dalam peraturan daerah terkait larangan prostitusi sesuai dengan hukum pidana Islam?. Ketiga, apakah sanksi pidana bagi pelaku prostitusi dalam peraturan-peraturan daerah terkait prostitusi di Indonesia mengandung unsur penjera. Keempat, Kebijakan apa yang tepat dapat diterapkan di Indonesia untuk mencegah dan menanggulangi prostitusi.

\section{Pengertian dan Landasan Teori Prostitusi}

Prostitusi atau pelacuran dalam kamus Bahasa Indonesia dijelaskan berasal dari kata lacur yang berarti malang, celaka, sial, gagal, atau buruk laku. Pelacur adalah perempuan yang melacur, sundal, wanita tuna susila. Pelacuran adalah perihal menjual diri sebagai pelacur, penyundalan. ${ }^{4}$ Menurut William Benton dalam Encyclopedia Britanica, pelacuran dijelaskan sebagai praktik hubungan seksual yang dilakukan sesaat, yang kurang lebih dilakukan dengan siapa saja (promiskuitas) ${ }^{5}$ untuk imbalan berupa uang. ${ }^{6}$ Sedangkan secara terminologis pelacuran atau prostitusi adalah penyediaan layanan seksual yang dilakukan oleh laki-laki atau perempuan untuk mendapatkan uang atau kepuasan. ${ }^{7}$ Menurut Mulia, T.S.G et.al dalam Ensiklopedia Indonesia dijelaskan bahwa pelacuran itu bisa dilakukan baik oleh kaum wanita maupun pria. Jadi ada persamaan predikat pelacuran antara laki-laki dan wanita yang bersama-sama melakukan perbuatan hubungan kelamin diluar perkawinan. Dalam hal ini, cabul tidak hanya berupa hubungan kelamin diluar nikah saja, akan tetapi termasuk pula peristiwa homoseksual dan permainan-permainan seksual lainnya. ${ }^{8}$

${ }^{4}$ W.J.S Poerdarmita, Kamus Umum Bahasa Indonesia (Jakarta: PN Balai Pustaka, 1984).

${ }^{5}$ Promiskuitas adalah hubungan seks secara bebas dan ketidakacuhan emosional, melakukan hubungan seks tanpa emosi, tanpa perasaan cinta kasih atau afeksi dan dilakukan dengan pria manapun juga, dengan banyak laki-laki.

${ }^{6}$ Tahnh-Dam Truong, Pariwisata dan Pelacuran di Asia Tenggara, trans. oleh Moh. Arif (Jakarta: LP3ES, 1992).

${ }^{7}$ Robert P.Masland dan dan Jr. David Estridge, Apa yang Ingin Diketahui Remaja Tentang Seks (Jakarta: Bumi Aksara, 1987).

${ }^{8}$ Kartini Kartono, Patologi Sosial (Jakarta: PT. Raja Grafindo Persada, 1997). 
Orang yang melakukan perbuatan prostitusi disebut pelacur yang dikenal juga dengan WTS atau Wanita TunaSusila.' Selain disebut dengan pelacur dan WTS, dikenal juga istilah pekerja seks/pekerja seks komersial (sex workers). Pekerja seks menjadikan seks sebagai pekerjaan untuk menghasilkan pendapatan dari menjual jasanya. Dalam tulisan ini, penulis menggunakan istilah pekerja seks. Pekerja seksual di semua negara dapat ditemukan. Praktik prostitusi secara global dideskripsikan dari penelitian legalitas pada 100 negara. Jumlah negara yang ilegal prostitusi sebesar 39\%. Negara yang legal prostitusi sebesar 49\%, dan legal terbatas (limited legality) sebesar $12 \%$. Prosentase ini cukup mencengangkan dan mengagetkan penulis. Selanjutnya prosentase tersebut dapat dilihat dalam grafik 1. Sebagai berikut:

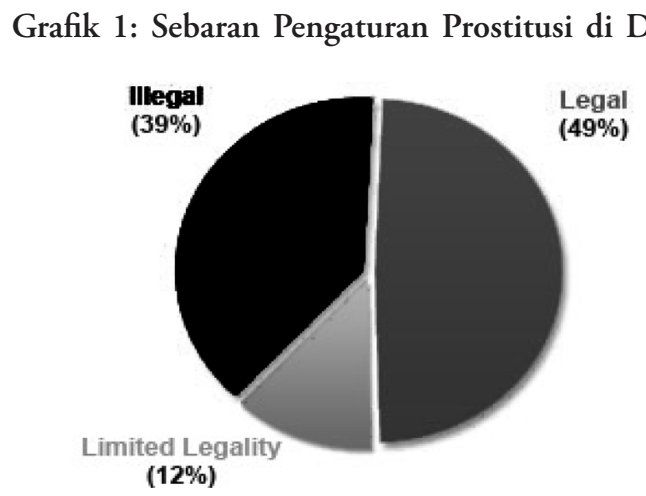

Sumber: www.ProCon.org ${ }^{10}$

Berdasarkan jumlah penduduk, prostitusi pada negara yang ilegal sebanyak 2,05 milyar penduduk atau 38\%. Jumlah penduduk pada negara yang legal prostitusi sebanyak 1,41 milyar atau 26\%. Sedangkan negara yang melegalkan dengan terbatas (limited legality) sebanyak 1,91 milyar orang atau 36\%. Sebaran tersebut dapat dilihat dalam grafik 2.

${ }^{9}$ Kartini Kartono, Patologi Sosial (Jakarta: PT. Raja Grafindo Persada, 1997).

${ }^{10}$ Editor, "100 Countries and Their Prostitution Policies," 12 Januari 2017, http:// prostitution. $\neg$ pro $\neg$ con.org/view.resource.php? resourceID=000772. 


\section{Grafik 2: Sebaran Jumlah Penduduk}

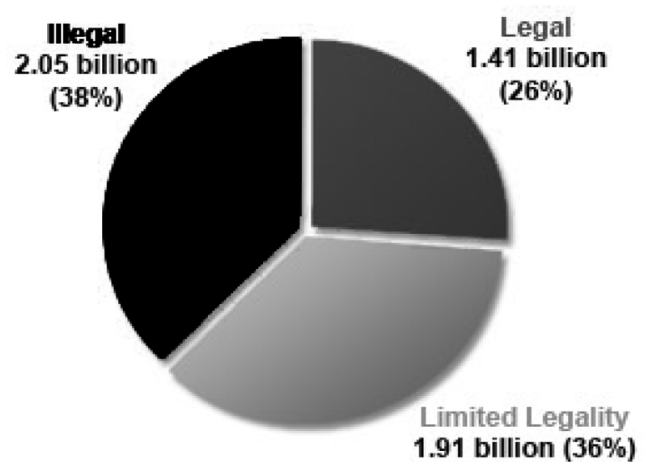

Sumber:www.ProCon.Org. ${ }^{11}$

Procon.org melakukan riset terhadap 100 negara terkait legalitas prostitusi. Negara-negara ini dipilih adalah termasuk negara yang pemeluk agamanya besar, wilayah geografis, dan kebijakan terhadap prostitusi. Procon.org memasukkan dokumen pemerintah mengenai prostitusi seperti undang-undang, keputusan pengadilan, informasi pekerjaan, dan lainnya dengan nama negara. Sementara upaya-upaya telah dilakukan untuk menjamin keakuratan data yang diberikan, tidak bergantung pada informasi ini tanpa terlebih dahulu memeriksa edisi resmi dari hukum yang berlaku. Data terkait legalitas prostitusi di 100 negara dapat dilihat dalam tabel 1.

${ }^{11}$ Editor, "100 Countries and Their Prostitution Policies," 12 Januari 2017, http:// prostitution. $\neg$ pro $\neg$ con.org/view.resource.php? resourceID=000772. 
Tabel 1 : legalitas Prostitusi di 100 Negara

\begin{tabular}{|c|c|c|c|c|}
\hline \multicolumn{2}{|c|}{ Hlegal in 39} & $\begin{array}{l}\text { Limited Legality } \\
\text { in } 12\end{array}$ & \multicolumn{2}{|c|}{ Legal in 49} \\
\hline $\begin{array}{l}\text { 1. Afghanistan } \\
\text { 2. Albania } \\
\text { 3. Angola } \\
\text { 4. Antigua and } \\
\text { Barbuda } \\
\text { 5. Bahamas } \\
\text { 6. Barbados } \\
\text { 2. Cambordia } \\
\text { 8. China } \\
\text { (including } \\
\text { Taiwan) } \\
\text { 9. Croatia } \\
\text { 10. Cuba } \\
\text { 11. Dominica } \\
\text { 12. Egypt } \\
\text { 13. Grenada } \\
\text { 14. Guyana } \\
\text { 15. Haiti } \\
\text { 16. Iran } \\
\text { 17. Iraq } \\
\text { 18. Jamaica } \\
\text { 19. Jordan } \\
\text { 20. Kenva } \\
\text { 21. Korea, North } \\
\text { 22. Korea, South } \\
\text { 23. Liberia } \\
\text { 24. Lithuania } \\
\text { 25. Malta } \\
\text { 26. Philippines }\end{array}$ & $\begin{array}{ll}\text { 27. } & \text { Romania } \\
28 . & \text { Fwanda } \\
29 . & \text { Saint Kitts } \\
\text { and Nevis } \\
\text { 30. Saint Lucia } \\
31 .\end{array}$ & $\begin{array}{l}\text { 1. Australia } \\
\text { 2. Bangladesh } \\
\text { 3. Bulgaria } \\
\text { 4. Canada } \\
\text { 5. Iceland } \\
\text { 6. India } \\
\text { 7. Japan } \\
\text { 8. Malaysia } \\
\text { 9. Spain } \\
\text { 10. Sweden } \\
\text { 11. United } \\
\text { States } \\
\text { 12. Norway }\end{array}$ & $\begin{array}{l}\text { 1. Argentina } \\
\text { 2. Armenia } \\
\text { 3. Austria } \\
\text { 4. Belgium } \\
\text { 5. Belize } \\
\text { 6. Bolivia } \\
\text { 7. Brazil } \\
\text { 8. Chile } \\
\text { 9. Colombia } \\
\text { 10. Costa Rica } \\
\text { 11. Cyprus } \\
\text { 12. Czech } \\
\text { Republic } \\
\text { 13. Denmark } \\
\text { 14. Dominican } \\
\text { Republic } \\
\text { 15. Ecuador } \\
\text { 16. El Salvador } \\
\text { 17. Estonia } \\
\text { 18. Ethiopia } \\
\text { 19. Finland } \\
\text { 20. France } \\
\text { 21. Germany } \\
\text { 22. Greece } \\
\text { 23. Guatemala } \\
\text { 24. Honduras } \\
\text { 25. Hungary } \\
\text { 26. Indonesia }\end{array}$ & $\begin{array}{l}\text { 27. Ireland } \\
\text { 28. Israel } \\
\text { 29. Italy } \\
\text { 30. Kyrgyzstan } \\
\text { 31. Latvia } \\
\text { 32. Luxembourg } \\
\text { 33. Mexico } \\
\text { 34. Netherlands } \\
\text { 35. New Zealand } \\
\text { 36. Nicaragua } \\
\text { 37. Panama } \\
\text { 38. Paraguay } \\
\text { 39. Peru } \\
\text { 40. Poland } \\
\text { 41. Portugal } \\
\text { 42. Senegal } \\
\text { 43. Singapore } \\
\text { 44. Slovakia } \\
\text { 45. Switzerland } \\
\text { 46. Turkey } \\
\text { 47. United } \\
\text { Kingdom } \\
\text { (including } \\
\text { Scotland) } \\
\text { 48. Uruguay } \\
\text { 49. Venezuela }\end{array}$ \\
\hline
\end{tabular}

Sumber: diolah dari situs procon.org ${ }^{12}$

Teori yang relatif tepat untuk mengkaji permasalahan di atas adalah sebagai berikut. Pertama, teori kritik hukum (critical legal studies). Teori kritik hukum adalah teori hukum yang muncul atas ketidakpuasan terhadap teori dan praktik hukum pada tahun tujuh puluhan di Amerika Serikat. Karakteristik dari teori kritik hukum adalah sebagai berikut:

1. Mengkritik hukum yang berlaku yang nyatanya memihak ke politik dan sama sekali tidak netral.

2. Mengkritik hukum yang sarat dan dominan dengan ideologi tertentu.

3. Mempunyai komitmen yang besar terhadap kebebasan individual sesuai batasan-batasan tertentu.

4. Kurang mempercayai bentuk-bentuk kebenaran yang abstrak dan pengetahuan yang benar-benar objektif.

5. Menolak unsur kebenaran dari ilmu pengetahuan hukum, dan

${ }^{12}$ Editor, "100 Countries and Their Prostitution Policies," 12 Januari 2017, http:// prostitution. $\neg$ pro $\neg$ con.org/view.resource.php? resourceID $=000772$. 
menolak pula kepercayaan terhadap unsur keadilan, ketertiban, dan kepastian hukum yang obyektif, sehingga mereka mengubah haluan hukum untuk kemudian digunakan sebagai alat untuk menciptakan emansipasi dalam dunia politik, ekonomi dan sosial budaya.

6. Menolak perbedaan antara teori dan praktik.Menolak juga perbedaan antara fakta dan nilai yang merupakan karakteristik dari paham liberal. Dengan demikian teori ini menolak kemungkinan teori murni (pure theory) tetapi lebih menekankan pada teori yang memiliki daya pengaruh terhadap transformasi sosial yang praktis.

Tulisan ini, kritik atas peraturan daerah tentang larangan prostitusi dalam aspek pemidanaan dengan cara berikut:

1. Kritik secara bahasa (gramatikal) yaitu suatu cara mengkaji peraturan perundang-undangan menurut arti kata-kata (istilah) yang terdapat dalam peraturan daerah.

2. Kritik secara historis yaitu mengkaji peraturan daerah dengan cara melihat sejarah terbentuknya suatu peraturan daerah.

3. Kritik secara sistematis yaitu mengkaji pasal yang satu dengan pasal yang lain dalam suatu peraturan daerah yang bersangkutan, atau dengan peraturan daerah lain, serta membaca penjelasan peraturan daerah tersebut sehingga dapat dipahami maksudnya.

4. Kritik secara teleologis sosiologis yaitu mengkaji makna peraturan daerah itu ditetapkan berdasarkan tujuan kemasyarakatan, artinya peraturan daerah disesuaikan dengan hubungan dan situasi sosial yang baru.

5. Kritik secara autentik yaitu mengkaji secara resmi yang diberikan oleh pembuat peraturan daerah tentang arti kata-kata yang digunakan dalam undang-undang tersebut.

Kedua, teori legislasi digunakan untuk menjawab permasalahan terkait dengan kedudukan peraturan-peraturan daerah dalam tata urutan peraturan perundang-undangan. Ketiga, teori pemidanaan hukum Islam dipergunakan untuk menjawab permasalahan pemidanaan yang ditetapkan dalam peraturan daerah terkait larangan prostitusi apakah sesuai dengan pidana Islam. Dalam penggunaan ini penerapan pidana prostitusi lebih pada tujuan penjeraan (detterence). Keempat, teori prostitusi (theory of 


\section{prostitution) dipergunakan untuk menyelesaikan permasalahan yang terkait} dengan hal-hal terkait prostitusi seperti motivasi prostitusi, penyebab, dampak ekonomis. ${ }^{13}$ Kelima, teori abolisi yang dipergunakan untuk memecahkan permasalahan kebijakan negara dalam mengatur prostitusi. ${ }^{14}$ Maka dalam teori ini, penulis menerapkan abolisi sebagai langkah yang tepat untuk mengatur prostitusi di Indonesia.

${ }^{13}$ Terkait hal tersebut, beberapa tulisan telah mengulasnya, di antaranya Carolina Nitimiharjo, "Peran Sistem Kepribadian dan Lingkungan dalam Perilaku Prostitusi." Jurnal Psikologi 5, no. 1 (2000): h. 56-63. Mutimmatul Faidah, "Pusaran Ekonomi di Balik Bisnis Prostitusi di Lokalisasi Dolly-Jarak Surabaya." Lentera 10, no. 1 (2014): h. 17-29. Astridya Paramita, Widjiartini Widjiartini, and Paiman Soeparmanto. "Pelayanan Kesehatan Reproduksi Remaja oleh Puskesmas yang di Wilayah Kerjanya Terdapat Lokasi Prostitusi (Studi di Kota Malang dan Kabupaten Tulungagung)." Buletin Penelitian Sistem Kesehatan 9, no. 3 Jul (2006). Yayan Sakti Suryandaru, "Hegemoni dan Reproduksi Kekuasaan dalam Perdagangan Perempuan (Trafficking) untuk Prostitusi." Jurnal Manusia, Kebudayaan, dan Politik (2001). Cemi Fitriani Jamal, "Politik Prostitusi Kota Surabaya (Studi Deskriptif: Eksistensi Dolly)." Junal Politik Muda, Universitas Airlangga 2, no. 1 (2013). Lanny Carolina Maria Lang, "Perlindungan Hukum Terhadap Hak Anak Korban Praktik Prostitusi dari Wisatawan." Lex Et Societatis 2, no. 1 (2014). A. Sunarto AS, "Kyai dan Prostitusi: Pendekatan Dakwah KH. Muhammad Khoiron Suaeb di Lokalisasi Kota Surabaya." Jurnal Komunikasi Islam 3, no. 2 (2012). Oksidelfa Yanto, "Prostitusi Online Sebagai Kejahatan Kemanusiaan Terhadap Anak: Telaah Hukum Islam dan Hukum Positif." AHKAM: Jurnal Ilmu Syariah 16, no. 2 (2016): h. 187-196. Nida Issabela, and Wiwin Hendriani. "Resiliensi pada Keluarga yang Tinggal di Lingkungan Lokalisasi Dupak, Bangunsari." Jurnal Insan Media Psikologi 12, no. 3 (2012). Soleh Amini Yahman, "Prostitusi: Antara Masalah Sosial, Ekonomi, Moral atau Etika Sosial." Indigenous: Jurnal Ilmiah Psikologi (2007). Rini Fathonah, "Analisis Terhadap Faktor Penyebab Prostitusi pada Anak." JURNAL POENALE 3, no. 4 (2016). Lutfi Irwansyah, "Kemiskinan, Keluarga dan Prostitusi pada Remaja." Seminar Asean 2nd Psychology \& Humanity. Psychology Forum UMM, 2016. Erianjoni, and Ikhwan Ikhwan. "Pola dan Jaringan Prostitusi Terselubung di Kota Padang." Humanus 11, no. 2 (2012): h. 112118. Vivi Ambarwati, "Fenomena Prostitusi di Pantai Samas Bantul Yogyakarta." DIMENSIA 6, no. 1 (2012). Astry Sandra Amalia, "Dampak Lokalisasi Pekerja Seks Komersial (PSK) Terhadap Masyarakat Sekitar (Studi Kasus di Jalan Soekarno-Hatta Km. 10 Desa Purwajaya Kabupaten Kutai Kartanegara).” eJournal Administrasi Negara 1 (2013).

${ }^{14}$ Dalam konteks regulasi dan adat, persoalan regulasi terkait pencegahan prostitusi terdapat dalam tulisan Kondar Siregar, "Model Pengaturan Hukum tentang Pencegahan Tindak Prostitusi Berbasis Masyarakat Adat Dalihan Na Tolu." Medan: Perdana Mitra Handalan (2015). Cindika Eka Pebriana, dkk, "Analisis Yuridis Kebijakan Hukum Pidana dalam Menanggulangi Tindak Pidana Prostitusi Melalui Media Online Sebagai Kejahatan Mayantara (Studi Putusan No. 228/PID. B/2015. PN. PGP).” Jurnal Diponegoro Law Review, Volume5, Nomor 3 (2016). Ganang Adityo Wicaksono, "Deligitimasi Kebijakan Penataan Ulang Wisata Prostitusi Dolly: Studi Deskriptif Perlawanan Komunitas Dolly." PhD diss., Universitas Airlangga, 2012. Arya Mahardhika Pradana, "Tinjauan Hukum Pidana Terhadap Prostitusi dan Pertanggungjawaban Pidana Para Pihak yang Terlibat dalam Prostitusi." Jurnal Hukum \& Pembangunan 45, no. 2 (2015): h. 276-307. Melinda Novi Sari, Madiasa Ablisar, and Rafiqoh Lubis. "Kebijakan Hukum Pidana dalam Penanggulangan Tindak Pidana Prostitusi Melalui Media Online.” Jurnal Mahupiki 1, no. 01 (2014). Raisanta Wongso, "Kejahatan Cyber Berbasis Prostitusi Ditinjau dari Undang-Undang Nomor 11 Tahun 2008 Tentang Informatika Transaksi dan Elektronik." Lex Privatum 4, No. 4 (2016). 


\section{Kedudukan Peraturan Daerah Terkait Larangan Prostitusi di Indonesia dalam Tata Urutan Peraturan Perundang-Undangan}

Peraturan daerah adalah sebuah produk legislasi yang dibuat atas inisiasi DPRD dan atau pemerintah daerah. Penyusunan sebuah peraturan daerah didasarkan atas dasar urgensi mendesak pada lingkungan daerah. Dasar dari pembuatan sebuah peraturan daerah adalah Undang-Undang Nomor 12 Tahun 2011 tentang Pembentukan Peraturan Perundangundangan dan Undang-Undang Nomor 23 Tahun 2014 tentang Peraturan Daerah.

Peraturan daerah terkait larangan prostitusi di Indonesia telah disusun dan diterapkan di sekitar 50 kabupaten/kota. Penggunaan istilah laranganpun bervariasi, ada yang menggunakan kata prostitusi, pelacuran, tuna susial, maksiat, khalwat. Penulis menyimpulkan bahwa perbedaan kata dalam titel judul peraturan daerah memiliki persamaan yaitu pada praktik prostitusi. Tentu praktik prostitusi yang dimaksud dalam peraturan daerah terkait dengan mucikari, bordil, dan pelacuran. Pelaku praktik itu dipidana dengan hukuman yang bervariasi dengan catatan tidak boleh melebih unsur yang tertuang dalam Pasal 15 Undang-Undang Nomor 12 Tahun 2011. Secara hirarkis vertikal dengan kedua undang-undang a quo, maka perda larangan prostitusi adalah kuat. Namun bila diuji dengan undang-undang lainnya, maka perda larangan prostitusi banyak bertentangan.

Perda larangan prostitusi berisikan ketentuan-ketentuan yang bersifat multitafsir, sehingga keadaan yang demikian sangat jelas tidak diperkenankan oleh teori hukum, terutama hukum pidana. Dalam hukum pidana, hal ini terkait erat dengan asas yang sangat fundamental, yaitu asas legalitas. Berkaitan dengan asas legalitas, menurut Machteld Boot dengan mengutip pendapat Jescheck dan Weigend, paling tidak ada empat syarat yang termasuk dalam asas tersebut. Lebih lanjut Boot menyatakan:

"The formulation of the Gesetzlichkeitsprinzip in Article $1 \mathrm{StGb}$ is generally considered to include four separate requirements. First, conduct can only be punished if the punishability as well as the accompanying penalty had been determined before the offence was committed (nullum crimen, noela poena sine lege praevia). Furthermore, these determinations have to be included in statutes (Gesetze): nullum crimen, noela poena sine lege scripta. 
These statutes have to be definite (bestimmt): nullum crimen, noela poena sine lege certa. Lastly, these statutes may not be applied by analogy which is reflected in the axiom nullum crimen, noela poena sine lege stricta."

Menimbang bahwa berdasarkan apa yang dikemukakan oleh Boot, ada beberapa hal yang berkaitan dengan asas legalitas, yaitu:

1. Prinsip nullum crimen, noela poena sine lege praevia. Artinnya, tidak ada perbuatan pidana, tidak ada pidana tanpa undangundang sebelumnya. Konsekuensi dari makna ini adalah ketentuan hukum pidana tidak boleh berlaku surut. Makna ini dalam sejarah perkembangan asas legalitas telah disimpangi di beberapa negara dengan alasan melindungi kepentingan negara dan bahaya yang ditimbulkan terhadap masyarakat.

2. Prinsip nullum crimen, nulla poena sine lege scripta. Artinya, tidak ada perbuatan pidana, tidak ada pidana tanpa undang-undang tertulis. Konsekuensi dari makna ini adalah semua ketentuan pidana harus tertulis. Dengan kata lain, baik perbuatan yang dilarang, maupun pidana yang diancam terhadap perbuatan yang dilarang harus tertulis secara expresiv verbis dalam undang-undang;

3. Prinsip nullum crimen, nulla poena sine lege certa. Artinya, tidak ada perbuatan pidana, tidak ada pidana tanpa aturan undangundang yang jelas. Konsekuensi selanjutnya dari makna ini adalah bahwa rumusan perbuatan pidana harus jelas sehingga tidak bersifat multitafsir yang dapat membahayakan bagi kepastian hukum. Demikian pula dalam hal penuntutan, dengan rumusan yang jelas, penuntut umum akan dengan mudah menentukan mana perbuatanperbuatan yang dikualifikasikan sebagai perbuatan pidana dan mana yang bukan.

4. Prinsip nullum crimen, noela poena sine lege stricta. Artinya, tidak ada perbuatan pidana, tidak ada pidana tanpa undang-undang yang ketat. Konsekuensi dari makna ini secara implisit tidak memperbolehkan analogi. Ketentuan pidana harus ditafsirkan secara ketat sehingga tidak menimbulkkan perbuatan pidana baru.

Apabila diuji dengan KUHAP, maka Perda larangan prostitusi jelas bertentangan dengan ketentuan umum hukum acara pidana yang berlaku 
di Indonesia, yaitu Undang-Undang Nomor 8 Tahun 1981 tentang Kitab Undang-Undang Hukum Acara Pidana (KUHAP) Indonesia, di antaranya mengenai penyidik sebagaimana yang termaktub dalam Pasal 10 ayat (1) Perda Kabupaten Bantul, dengan menempatkan Polisi Pamong Praja sebagai penegak hukum terhadap Perda tersebut. Hal ini jelas tidak diatur dalam KUHAP, karena yang ditempatkan sebagai penyidik menurut KUHAP hanyalah Lembaga Kepolisian dan Kejaksaan. Hal lain yang juga menjadi catatan adalah tindakan yang dapat dilakukan terhadap orang yang disangka telah melanggar ketentuan pidana dari Perda. Dapat dikatakan Perda larangan prostitusi dalam memandang orang yang diduga melakukan pelanggaran pidana dalam Perda hanyalah secara subjektif hasil penilaian dari penegak hukum dalam Perda tersebut, termasuk dalam melakukan penangkapan terhadap tersangka. Hal ini sangat jelas dan tegas bertentangan dengan KUHAP yang menetapkan bahwa seseorang untuk dapat ditetapkan sebagai tersangka haruslah berdasarkan bukti permulaan yang cukup. Hal ini paling tidak dapat disimpulkan dari ketentuan Pasal 17 KUHAP yang menyebutkan: "Perintah penangkapan dilakukan terhadap seseorang yang diduga keras melakukan tindak pidana berdasarkan bukti permulaan yang cukup". Artinya, untuk melakukan proses pidana terhadap seseorang berdasarkan deskriptif faktual dan bukti permulaan yang cukup harus ada suatu praduga bahwa orang tersebut telah melakukan suatu perbuatan pidana yang dimaksud. Dengan demikian tidak bersesuaian dengan ketentuan KUHAP dan sangat rawan disalahgunakan oleh penegak hukum sebagaimana dimaksud dalam Perda. Tegasnya, berdasarkan asas lex superior derogat legi inferior, tentunya perda larangan prostitusi tidak dapat diberlakukan karena bertentangan dengan KUHAP sebagai hukum yang lebih tinggi.

Selanjutnya pengujian Perda larangan prostitusi yang juga merujuk dan menjadikan Nomor 8 Tahun 1981 tentang Hukum Acara Pidana (Lembaran Negara Tahun 1981 Nomor 76, Tambahan Lembaran Negara Nomor 3209) atau KUHAP sebagai landasan pembentukannya, namun lagi-lagi pada saat yang sama membuat ketentuan yang menyimpang dari KUHAP. Secara khusus dalam hal ini yang berkenaan dengan salah tangkap. Dalam KUHAP tatkala terjadi keadaan demikian, kepada pihak yang dirugikan diberi upaya hukum untuk menempuh pra-peradilan. 
Sementara jika keadaan demikian terjadi dalam konteks pelaksanaan Perda larangan prostitusi, kepada mereka yang dirugikan tidak disediakan jalan hukum apapun atas kerugian yang telah diderita atau dialaminya.

Berdasarkan tinjauan Hukum Pidana bahwa Perda larangan prostitusi merujuk dan sekaligus menjadikan Undang-Undang Nomor 1 Tahun 1946 tentang Peraturan Hukum Pidana jo. Undang-Undang Nomor 73 Tahun 1958 tentang Menyatakan Berlakunya Undang-Undang Nomor 1 Tahun 1946 tentang Peraturan Hukum Pidana Untuk Seluruh Wilayah Republik Indonesia dan Mengubah Kitab Undang-Undang Hukum Pidana (Lembaran Negara Tahun 1950 Nomor 127, Tambahan Lembaran Negara Nomor 1660) atau KUHP sebagai landasan pembentukannya. Namun, pada saat yang sama, Perda larangan prostitusi memberikan pengaturan yang berbeda, bahkan bertentangan, dengan pengaturan yang terdapat dalam KUHP berkenaan dengan "perbuatan cabul", "pelacuran", dan "mucikari", padahal Perda larangan prostitusi bukanlah lex specialis dari KUHP. Dengan demikian, dalam konteks ini tidak berlaku asas hukum lex specialis derogat legi generali. Bahkan, sebagai peraturan perundang-undangan yang kedudukannya lebih rendah (lex inferiori), perda larangan prostitusi nyata-nyata telah mengatur secara berbeda terhadap hal-hal yang diatur oleh peraturan perundang-undangan yang kedudukannya lebih tinggi (lex superiore), sehingga dalam hubungan iniberlaku asas hukum lex superiore derogat legi inferiori. Kitab Undang-Undang Hukum Pidana(KUHP) tidak melarang pekerjaan seks secara spesifik. KUHP melarang fasilitasi tindak asusila oleh pihak lain sebagai mata pencaharian (Pasal 296) perdagangan perempuan (Pasal 297), penggelandangan (Pasal 505) dan hidup dari penghasilan seorang pekerja seks perempuan (Pasal 506).

Perda larangan prostitusi juga merujuk dan menjadikan UndangUndang Nomor 32 Tahun 2004 tentang Pemerintahan Daerah (Lembaran Negara Republik Indonesia Tahun 2004 Nomor 125, Tambahan Lembaran Negara Nomor 4437) sebagaimana telah diubah dengan Undang-Undang Nomor 8 Tahun 2005 tentang Penetapan Peraturan Pemerintah Pengganti Undang-Undang Nomor 3 Tahun 2005 tentang Perubahan atas Undang-Undang Nomor 32 Tahun 2004 tentang Pemerintahan Daerah Menjadi Undang-Undang (Lembaran Negara Republik 
Indonesia Tahun 2005 Nomor 108, Tambahan Lembaran negara Nomor 4548) (selanjutnya disebut UU Pemda) sebagai landasan pembentukannya. Dalam konteks ini, meskipun benar bahwa sesuai dengan ketentuan Pasal 14 ayat (1) huruf f substansi yang diatur dalam Perda merupakan urusan yang termasuk ke dalam kewenangan Pemerintahan Daerah Kabupaten/Kota, pelaksanaan kewenangan ini tidaklah boleh dilakukan sedemikian rupa sehingga menjadi keluar dari nature penyelenggaraan pemerintahan sebagaimana dimaksud dalam Pasal 11 UU Pemda yang menyatakan, antara lain, ayat (1), "Penyelenggaraan urusan pemerintahan dibagi berdasarkan kriteria eksternalitas, akuntabilitas, dan efisiensi dengan memperhatikan keserasian hubungan antar susunan pemerintahan;" ayat (2) "Penyelenggaraan urusan pemerintahan sebagaimana dimaksud pada ayat (1) merupakan pelaksanaan hubungan kewenangan antara Pemerintah dan pemerintahan daerah provinsi, kabupaten dan kota atau antar pemerintahan daerah yang saling terkait, tergantung, dan sinergis sebagai satu sistem pemerintahan". Dalam konteks ini, dengan memperhatikan kembali pertimbangan-pertimbangan sebelumnya, Pperda larangan prostitusi telah nyata tidak mengindahkan keserasian hubungan antar susunan pemerintahan sehingga dengan sendirinya kesalingterkaitan, kesalingtergantungan, sinergitas sebagai satu sistem pemerintahan tidak terjadi, bahkan terganggu.

Pengaturan prostitusi diatur pula dalam Undang-Undang Pornografi Tahun 2008 yang mendefinisikan pornografi secara luas mencakup gambar, foto, percakapan, bahasa tubuh, atau pesan-pesan apapun dalam berbagai bentuk komunikasi dan pertunjukan publik yang mengandung kecabulan yang melanggar norma moral. Materi edukasional untuk pencegahan HIV dan promosi kesehatan tidak dimaksudkan untuk masuk ke dalam definisi pornografi di bawah peraturan hukum ini. Walaupun demikian, terdapat kekhawatiran bahwa definisi ini terlalu luas sehingga peraturan hukum ini bisa menyebabkan pekerja pencegahan melakukan sensor sendiri dan menghambat sumber-sumber edukasi sebaya dan publikasi promosi kesehatan yang berkaitan dengan pekerjaan seks.

Undang-Undang Nomor 21 tahun 2007 tentang Pemberantasan Tindak Pidana Perdagangan Orang mengatur praktik prostitusi dengan 
pasal yang mengatur human trafficking. Human trafficking adalah segala bentuk jual beli terhadap manusia, dan juga ekploitasi terhadap manusia itu sendiri seperti pelacuran (bekerja atau layanan paksa), perbudakan atau praktik yang menyerupainya, dan juga perdagangan atau pengambilan organ tubuh manusia. Tindak Pidana Perdagangan Orang yang mana pasalnya dapat menjerat pelaku bisnis prostitusi merujuk kepada Pasal 2 ayat (1) dan Ayat (2). Selanjutnya Undang-Undang Nomor 23 Tahun 2002 tentang Perlindungan Anak. Ketentuan Pidana dalam UndangUndang ini dapat menjerat pelaku bisnis prostitusi. Pasal 81 (1) dan Pasal 82, Pasal 88. Undang-Undang Nomor 23 Tahun 2004 tentang Penghapusan Kekerasan Dalam Rumah Tangga. Pasal 5, 8, 47 mengatur secara implisit pelaku prostitusi.Undang-Undang Nomor 11 Tahun 2008 tentang Informasi dan Transaksi Elektronik tidak menyebutkan kata prostitusi dalam semua pasalnya. Kecuali pada pasal 27 yang berisikan tentang berbuatan perbuatan yang dilarang, menyebutkan kata kesusilaan yang menyangkut kepada hal-hal yang berbau pornografi. Isi pasal 27 UU ITE yaitu sebagai berikut: “(1) Setiap Orang dengan sengaja dan tanpa hak mendistribusikan dan/atau mentransmisikan dan/atau membuat dapat diaksesnya Informasi Elektronik dan/atau Dokumen Elektronik yang memiliki muatan yang melanggar kesusilaan.”

\section{Sanksi Pidana dalam Peraturan Daerah Terkait Larangan Prostitusi}

Pada tingkat daerah, serangkaian peraturan daerah diaplikasikan pada pekerja seks dan industri seks. Peraturan-peraturan ini mencakup pelarangan ketat terhadap pekerjaan seks hingga regulasi kompleks rumah bordil yang ditoleransi secara resmi. Peraturan daerahtersebut adalah:

1. Perda Nomor 5 Tahun 2002 tentang Larangan Perjudian, Prostitusi, dan Minuman Keras Kabupaten Cirebon.

2. Perda Nomor 6 Tahun 2003 tentang Larangan Gelandangan dan Pengemisan Serta Praktik Susila di Kota Medan. ${ }^{15}$

${ }^{15}$ Pasal 2 (3), dilarang membujuk atau memikat orang lain dengan dengan perkataanperkataan dan isyarat dan atau dengan perbuatan lainnya dengan maksud mengajak melakukan perbuatan pelacuran dijalan umum dan atau tempat yang diketahui/dikunjungi oleh orang lain baik perorangan atau beberapa orang;(4) dilarang dengan sengaja memanggil/mendatangkan seseorang, 
3. Perda Nomor 2 Tahun 2004 tentang Pemberantasan Pelacuran Kota Palembang. ${ }^{16}$

4. Perda Nomor 13 Tahun 2002 tentang Pemberantasan Maksiat di Propinsi Sumatera Selatan.

5. Perda Nomor 11 Tahun 2001 tentang Pemberantasan dan Pencegahan Maksiat Propinsi Sumatera Barat.

6. Perda Nomor 20 Tahun 2003 tentang Perubahan atas Peraturan Daerah Kota Bukittinggi Nomor 9 Tahun 2000 tentang Penertiban dan Penindakan Penyakit Masyarakat Kota Bukittinggi.

7. Perda Nomor 3 Tahun 2002 tentang Larangan Perbuatan Pelacuran dan Tuna Susila dalam Kabupaten Lahat. ${ }^{17}$

8. Perda Nomor 3 Tahun 2004 tentang Pencegahan, Pemberantasan dan Penindakan Penyakit Masyarakat Kota Padang Panjang.

9. Perda Nomor 2 Tahun 2004 tentang Pencegahan, Penindakan dan Pemberantasan Maksiat Kabupaten Padang Pariaman.

10. Perda Nomor 19 Tahun 2006 tentang Pencegahan dan Penanggulangan Maksiat Kabupaten Sawahlunto/Sijunjung.

beberapa orang untuk maksud melakukan perbuatan-perbuatan pelacuran/tuna susila.Pasal 5 (1) Barang siapa yang melanggar ketentuan pasal 2 peraturan daerah ini diancam pidana kurungan paling lama 6 (enam) bulan dan atau denda sebanyak-banyaknya Rp. 5.000.000,- (lima juta rupiah).

${ }^{16}$ Pasal 6, setiap orang dan badan dilarang: a. menjadi pelaku pelacuran; b. mendatangkan pelaku pelacuran; c. menyediakan tempat untuk pelacuran; d. mengelola pelacuran; e. melindungi atau menjadi pelindung pelacuran; f. memberi kesempatan untuk terjadinya pelacuran. Pasal 7,dilarang menggunakan jalan umum, lorong, gang, lapangan terbuka, taman, penginapan, hotel, losmen, motel, panti pijat, salon, diskotik, asrama, rumah kediaman, warung, lingkungan kerja dan tempat hiburan sebagai tempat melakukan pelacuran. Pasal 8 (1) pelacuran adalah perbuatan yang dilakukan setiap orang atau sekelompok orang dengan sadar, bertujuan mencari kepuasan syahwat di luar ikatan pernikahan yang sah dengan atau tanpa menerima imbalan baik berupa uang atau imbalan lain (2) termasuk dalam perbuatan pelacuran adalah: a. homoseks; b. lesbian; c. sodomi; d. pelecahan seksual; dan e. perbuatan porno lainnya.

${ }_{17}$ Pasal 2, setiap orang dilarang melakukan kegiatan pelacuran dan atau tuna susila dalam daerah Kabupaten Lahat dengan alasan atau dalih apapun. Pasal 3,setiap orang atau badan hukum dalam daerah Kabupaten Lahat dilarang: a. menyediakan tempat untuk kegiatan pelacuran atau tuna susila; b. menjadi pelacur atau tuna susila; c. mendatangkan pelacur atau tuna susila; d. menyediakan tempat pertemuan pelacur atau tuna susila; e. menjadi germo atau mucikari; $\mathrm{f}$. melindungi atau menjadi pelindung atau pelacur, tuna susila, germo atau mucikari; g. melakukan perbuatan cabul atau sejenisnya ditempat-tempat lainnya. Pasal 5 (1), pelanggaran atas ketentuan pasal 2 dan pasal 3 Peraturan Daerah ini diancam pidana kurungan serendah-rendahnya 3 (tiga) bulan dan setinggitingginya 6 (enam) bulan atau denda sekurang-kurangnya Rp.2.500.000,- dan atau setinggi-tingginya Rp.5.000.000,. (2) Tindak pidana sebagaimana dimaksud ayat (1) pasal ini adalah pelanggaran. 


\section{Perdes Nomor 5 Tahun 2006 tentang Pelaksanaan Hukuman Cambuk Desa Muslim Padang Kecamatan Gantarang Kabupaten Bulukumba.}

\section{Perda Nomor 6 Tahun 2002 tentang Ketertiban Sosial di Kota Batam. ${ }^{18}$}

\section{Perda Nomor 39 Tahun 1999 tentang Penertiban Tempat Pelacuran di Daerah Kota Kupang. ${ }^{19}$}

${ }_{18}$ Pasal 5, setiap orang atau badan yang berada dan atau berdomisili di Kota Batam dilarang: (1) menyediakan dan atau menggunakan bangunan atau tempat untuk melakukan perbuatan judi dan asusila. (2) melakukan perbuatan pemikatan untuk berbuat asusila. (3) melakukan usaha penampungan dan penyaluran pramuria untuk tempat-tempat hiburan dan sejenisnya tanpa seizin Walikota. (4) melakukan usaha penampungan, penyaluran dan perbuatan sebagai pengemis. (5) melakukan perbuatan sebagai gelandangan. Pasal 6 (1) Tempat-tempat yang patut diduga melakukan penyalahgunaan izin untuk praktik pelacuran atau perjudian dilakukan razia oleh Tim Gabungan Penegak Hukum. Pasal 7 (1),setiap orang dilarang bertingkah laku asusila di jalan, jalur hijau, taman, dan tempat-tempat umum lainnya; (2) setiap orang dilarang berpakaian yang tidak sesuai dan atau bertentangan dengan norma-norma agama dan budaya di tempat-tempat umum; (3) setiap orang berlainan jenis kelamin dilarang tinggal dan atau hidup satu atap layaknya suami istri tanpa diikat oleh perkawinan yang sah berdasarkan UndangUndang; (4) setiap orang berhak melaporkan orang-orang yang tinggal dan atau hidup satu atap layaknya suami istri tanpa diikat oleh perkawinan yang sah berdasarkan Undang-Undang kepada yang berwajib. Pasal 8 (1),terhadap lokasi-lokasi praktik pelacuran di Kota Batam yang telah ada sebelum Perda ini ditetapkan akan dilaksanakan pemindahan ke Pusat Rehabilitasi Sosial non-Panti; (2) pemindahan ke Pusat Rehabilitasi Sosial non-Panti yang dimaksud pada ayat (1) pasal ini dilakukan pembinaan oleh Pemerintah Kota Batam berupa: a. adanya pengawasan ketat sehingga jumlah pelacur tidak terjadi penambahan. b. secara teratur dilakukan pembinaan agama, sosial dan ekonomi. c. setelah dilakukan upaya sebagaimana huruf (a) dan (b) di atas, maka dalam waktu 3 (tiga) tahun berikutnya tempat tersebut akan ditutup. Pasal 9,setiap orang atau badan dilarang membentuk dan atau mengadakan perkumpulan yang mengarah kepada perbuataan asusila dan secara normatif tidak bisa diterima oleh budaya masyarakat. Pasal 16 (1), pelanggaran terhadap ketentuan-ketentuan dalam Peraturan Daerah ini diancam dengan pidana kurungan paling lama 3 (tiga) bulan dan atau denda paling banyak Rp. 5.000.000,- (lima juta rupiah). (2) Tindak pidana yang dimaksud dalam ayat (1) pasal ini adalah pelanggaran.

${ }^{19}$ Pasal 2 (1) Kepala Daerah berkewajiban mengatur, menerbitkan atau meniadakan tempattempat yang menurut keyakinan merupakan tempat pelacuran; (2) dalam hal pelaksanaan ketentuan sebagaimana dimaksud ayat (1) pasal ini, Kepala Daerah dapat menunjukan pejabat di lingkungan pemerintah Daerah. Pasal 3 (1) untuk tujuan pembinaan dan pengawasan dalam rangka rehabilitas sosial, Kepala Daerah dapat melakukan pengawasan di lokasi pelacuran; (2) dalam hal pengelolaan lokalisasi tersebut sebagaimana dimaksud ayat (1) pasal ini, Kepala Daerah kewajiban menuntut dan menetapkan pengolahan setelah memenuhi persyaratan yang ditentukan oleh pemerintah daerah serta ketentuan peraturan perundang-undangan yang berlaku; (3) jumlah maksimum pelacuran yang berada, dan menghuni atau menggunakan tempat pelacuran di lokalisasi serta kapasitas lokasi, ditetapkan oleh Kepala Daerah; (4) Kepala Daerah berkewenangan menutup lokasi sebagaimana di maksud ayat (1) pasal ini, apabila pengolahan tidak memenuhi persyaratan yang ditetapkan oleh pemerintah daerah serta ketentuan peraturan perundang-undangan yang berlaku atau untuk kebutuhan pembangunan, tata ruang atau alasan yang dapat dipertanggung jawabkan; (5) lokasi yang telah ditutup, dilarang bagi 


\section{Perda Nomor 15 Tahun 2002 tentang Larangan Perbuatan Prostitusi dan Tuna Susila dalam Wilayah Kota Bandar Lampung.}

\section{Perda Nomor 4 Tahun 2004 tentang Larangan Perbuatan Prostitusi,}

setiap orang untuk menggunakan, menghuni, mengunjungi atau berada sebagai tamu untuk tujuan pelacuran kecuali; Pasal 4 (1) kecuali pada lokasi pelacuran, setiap orang tidak diperbolehkan untuk menghuni ataupun menggunakan rumah bordil, hotel,losmen, penginapan, panti pijat, salon kecantikan maupun rumah kost atau tempat-tempat yang bukan peruntukan tempat pelacuran sebagai tempat untuk tujuan pelacuran; (2) setiap orang yang tingkah lakunya teridentifikasi sebagaipelacur, tidak diperbolehkan berkeliaran atau berjalan hilir-mudik di jalan-jalan umum, jalur hijau atau berada di sekitar losmen, penginapan, atau yang sejenis dengan itu, warung, rumah makan, restoran atau rumahrumah pertunjukan, salon kecantikan, atau pusat kebugaran; (3) apabila orang tersebut berada pada tempat-tempat sebagaimana dimaksud ayat (2) pasal ini atau diketemukan sedang melakukan upaya untuk tujuan pelacuran, pejabat yang berwenang berhak meminta keterangannya untuk pengusutan lebih lanjut atau dapat memerintahkannya dengan segera meninggalkan tempat-tempat tersebut. Pasal 5 (1),pengelola bertanggungjawab atas kebersihan, kesehatan, keamanan, dan ketertiban lingkungan lokalisasi maupun para pelacur; (2) pengelola diharuskan untuk memberikan laporan tentang data pelacuran yang memenuhi atau menggunakan tempat pelacuran, secara tertulis dan diketahui oleh Lurah setempat, kepada Kepala Daerah atau pejabat yang ditunjuk setiap 3 (tiga) bulan sekali; (3) dalam hal ini tidak memenuhi ketentuan ayat (2) dan atau ayat (3) pasal ini, Kepala Daerah kepada atau pejabat yang ditunjuk berkewajiban memberikan peringatan tertulis kepada pengelola sebanyak 3 (tiga) kali; (4) apabila dalam jangka waktu 1 (satu) bulan setelah diterima surat peringatan secara tertulis, pengelola tidak atau belum memenuhi ketentuan ayat (1) dan atau ayat (2) pasal ini, Kepala Daerah berkewajiban memberikan sangsi sesuai ketentuan perundang-undangan yang berlaku. Pasal 6 (1),para pelacuran diharuskan mentaati ketentuan yang ditetapkan oleh pengelola; (2) dalam hal pembinaan sebagaimana dimaksud pasal 3 ayat (1) Peraturan Daerah ini, para pengelola diharuskan mengikuti jadwal dan program pembinaan oleh Pemerintah Daerah; (3) setiap pelacur yang menghuni atau menggunakan tempat pada lokalisasi, wajib memiliki kartu kesehatan dan kartu pembinaan yang disediakan oleh pejabat yang ditunjuk yang bersangkutan dalam program pembinaan; (4) kartu kesehatan dan kartu pembinaan sebagaimana dimaksud ayat (3) pasal ini, harus ditandatangani oleh petugas setiap kali pemeriksaan kesehatan maupun mengikuti program pembinaan yang dilakukan oleh Pemerintah Daerah. Pasal 7 (1),pengunjung dilarang menggunakan atribut lembaga pemerintah atau atribut lembaga resmi lainnya untuk berada di lingkungan lokalisasi, kecuali apabila yang bersangkutan sedang melaksanakan tugas pada lokalisasi tersebut dan dapat dibuktikan dengan surat tugas; (2) pengunjung tidak diperbolehkan membawa sejata tajam, senjata api, obat-obat terlarang atau bahan/ benda yang dapat menimbulkan bahaya, mabuk-mabukan dan atau membuat keonaran/keributan di lokasi pelacuran; (3) apabila pengunjung yang melanggar ketentuan sebagaimana dimaksud ayat (2) pasal ini, pengelola berkewajiban melaporkan kepada petugas keamanan untuk dimintai keterangannya dalam rangka pengusutan lebih lanjut sesuai ketentuan perundangan-undangan yang berlaku. Pasal 8 (1),pengelola dilarang melibatkan orang perempuan yang belum cukup usia untuk melakukan pelacuran atau membiarkan pengunjung yang belum cukup usia berada berada di lingkungan lokasi pelacuran; (2) apabila ditemukan orang yang belum cukup usia sebagaimana dimaksud ayat (1) pasal ini, pejabat yang berwenang dapat melakukan tindakan hukum terhadap pengelola sesuai ketentuan perundang-undangan yang berlaku; (3) lokasi yang telah ditutup, dilarang bagi setiap orang untuk menggunakannya. Pasal 10 (1),barang siapa yang dengan sengaja maupun tidak sengaja melakukan pelanggaran terhadap ketentuan dalam Peraturan Daerah ini diancam pidana kurungan paling lama 6 (enam) bulan atau denda paling banyak Rp. 5.000.000,- (lima juta rupiah); (2) tindak pidanan sebagaimana dimaksud ayat (1) pasal ini adalah pelanggaran. 


\title{
Tuna Susila, dan Perjudian Serta Pencegahan Perbuatan Maksiat dalam Wilayah Kabupaten Lampung Selatan. ${ }^{20}$
}

\section{Perda Nomor 7 Tahun 2001 tentang Larangan Perbuatan Prostitusi dan Tuna Susila dalam Daerah Kabupaten Way Kanan.}

\section{Perda Nomor 26 Tahun 2002 tentang Penertiban dan Rehabilitasi Tuna Susila dalam Daerah Kota Palangkaraya.}

\section{Perda Nomor 10 Tahun 2007 Tentang Ketertiban Sosial Kabupaten Banjar. \\ 19. Perda Nomor 7 Tahun 2002 tentang Pelarangan Pelacuran dan Perbuatan Cabul Kabupaten Gresik.}

\author{
20. Perda Nomor 8 Tahun 2005 tentang Pelarangan Pelacuran Kota \\ Tangerang. ${ }^{21}$
}

${ }^{20}$ Pasal 3 (1) setiap orang atau badan dilarang melakukan perbuatan prostitusi dan tuna susila didalam wilayah Kabupaten Lampung Selatan; (2) larangan sebagaimana dimaksud pada ayat (1) pasal ini berlaku juga bagi siapapun yang karena tingkah lakunya patut diduga dapat menimbulkan perbuatan prostitusi dan tuna susila; (3) larangan sebagaimana dimaksud pada ayat (1) pasal ini juga berlaku bagi siapapun baik secara sendiri-sendiri, bersama-sama maupun berkelompok dengan sengaja mengusahakan tempat-tempat perbuatan prostitusi dan tuna susila; (4) setiap orang atau badan dilarang menjadi pelindung (becking) perantara dan atau menyediakan orang untuk melakukan perbuatan prostitusi dan tuna susila. Pasal 10 (1), barang siapa yang melanggar ketentuan larangan dalam Peraturan Daerah ini diancam: a. pembebanan biaya paksaan penegakan hukum seluruhnya atau sebagian. b. pidana kurungan paling lama 6 (enam) bulan atau denda Rp 5.000.000,- (lima juta rupiah) dengan atau tidak merampas barang tertentu untuk Daerah kecuali jika ditentukan lain dalam peraturan perundang-undangan; (2) jika seseorang melakukan lagi pelanggaran yang sama dengan pelanggaran pertama sebelum lewat jangka waktu 1 (satu) tahun sejak tanggal keputusan pengadilan atas pelanggaran pertama yang telah mempunyai kekuatan hukum tetap, maka pidana yang diajukan terhadap pelanggaran kedua dan seterusnya ditambah dengan sepertiga dari pidana kurungan pokoknya atau apabila dikenakan denda dapat ditambah dengan setengah dari pidana denda yang diancam untuk pelanggaran tersebut.

${ }^{21}$ Setelah Perda diberlakukan menurunnya jumlah angka pelacuran, dan juga dari mereka yang telah dibina umumnya hanya $10 \%$ saja yang kembali menjadi pelacur dan dikirim kembali ke Panti Rehabilitasi Sosial Karya Wanita Mulya Jaya. Pasal 2 (1), setiap orang di Daerah baik sendiri-sendiri ataupun bersama-sama dilarang mendirikan dan/atau mengusahakan atau menyediakan tempat dan/atau orang untuk melakukan pelacuran; (2) siapapun di Daerah dilarang baik secara sendiri ataupun bersama-sama untuk melakukan perbuatan pelacuran; (3) larangan sebagaimana dimaksud pada ayat (1) dan (2) pasal ini berlaku juga bagi tempat-tempat hiburan, hotel, penginapan atau tempat-tempat lain di Daerah. Pasal 3, setiap orang dilarang membujuk atau memaksa orang lain baik dengan cara perkataan, isyarat, tanda atau cara lain sehingga tertarik untuk melakukan pelacuran. Pasal 4 (1), setiap orang yang sikap atau perilakunya mencurigakan, sehingga menimbulkan suatu anggapan bahwa ia/mereka pelacur dilarang berada di jalan-jalan umum, di lapangan-lapangan, dirumah penginapan, losmen, hotel, asrama, rumah penduduk/ kontrakan, warung-warung kopi, tempat hiburan, gedung tempat tontonan, di sudut-sudut jalan 


\section{Perda Nomor 11 tahun 2003 tentang Pelarangan Prostitusi Kabupaten Ketapang.}

\section{Perda Nomor 14 Tahun 2001 tentang Penanganan Pelacuran Kabupaten Jember.}

\section{Perda Nomor 24 Tahun 2000 tentang Larangan Pelacuran dalam Kota Bengkulu.}

\section{Perda Nomor 5 Tahun 2007 tentang Pemberantasan Pelacuran di Kabupaten Lamongan. ${ }^{22}$}

\section{Perda Nomor 8 Tahun 2005 tentang Larangan Tempat Pelacuran dan Perbuatan Cabul Kota Malang. ${ }^{23}$}

atau di lorong-lorong atau tempat-tempat lain di daerah; (2) siapapun dilarang bermesraan, berpelukan dan/atau berciuman yang mengarah kepada hubungan seksual, baik di tempat umum atau di tempat-tempat yang kelihatan oleh umum. Pasal 9 (1),barangsiapa yang melanggar ketentuan Pasal 2 Ayat (1) dan ayat (2) Peraturan Daerah ini diancam kurungan paling lama 3 (tiga) bulan atau denda setinggi-tingginya Rp. 15.000.000,- (lima belas juta rupiah); (2) tindak pidana sebagaimana dimaksud ayat (1) pasal ini adalah pelanggaran.

${ }^{22}$ Selama tahun 2006, Satuan Polisi Pamong Praja telah mengadakan beberapa kali operasi/ razia terhadap pelacur dan berhasil menangkap 69 pelaku. Namun dari data yang diperoleh dari Pengadilan Negeri Lamongan, jumlah kasus pelacuran yang disidangkan di Pengadilan Negeri Lamongan hanya berjumlah 4 kasus (dengan hanya 4 tersangka). Hal ini menunjukkan betapa banyaknya pelaku pelacuran yang tertangkap oleh Polisi Pamong Praja namun tidak sampai ke Pengadilan. Setelah ditelusuri di Kantor Polisi Pamong Praja, ternyata memang pihak Polisi Pamong Praja selama tahun 2006 ini tidak pernah mengirimkan pelaku pelacuran untuk sidang di Pengadilan. Empat kasus yang disidangkan oleh Pengadilan tersebut ternyata hasil dari razia oleh pihak Kepolisian langsung.

${ }^{23}$ Pasal 2 di Kota Malang dilarang adanya tempat-tempat pelacuran dan perbuatan cabul baik yang dilakukan perorangan maupun yang dikoordinir oleh beberapa orang atau kelompok. Pasal 3 (1),dilarang bagi siapa saja berada di jalan umum atau tempat-tempat yang mudah dilihat umum, untuk mempengaruhi, membujuk, menawarkan, memikat orang lain dengan perkataan, isyarat, tanda-tanda atau perbuatan lain yang dimaksud mengajak melakukan zina atau perbuatan cabul; (2) dilarang bagi siapa saja berada di jalan umum atau tempat-tempat yang mudah dilihat umum maupun terselubung untuk melakukan perbuatan cabul; (3) dilarang bagi siapa saja berhenti atau berjalan mondar-mandir baik dengan kendaraan bermotor maupun tidak bermotor dan atau berjalan kaki di depan tempat-tempat tertentu, didekat rumah penginapan, pesanggrahan, rumah makan atau warung dan pada tempat-tempat umum yang dalam keadaan remang-remang atau gelap yang karena tingkah lakunya tersebut dapat mencurigakan atau menimbulkan suatu anggapan sebagai pelacur; (4) dilarang bagi siapa saja bertindak sebagai mucikari atau perantara dengan mengkoordinir satu atau beberapa orang untuk dipekerjakan sebagai pelacur dan atau menyediakan tempat untuk melakukan perbuatan zina atau perbuatan cabul; (5) dilarang bagi siapa saja bertindak sebagai becking yang melindungi pelacur dan atau memberikan sarana dan prasarana untuk melakukan perbuatan zina atau perbuatan cabul. Pasal 5,pelanggaran terhadap ketentuan sebagaimana dimaksud dalam Pasal 2, Pasal 3 dan Pasal 4, diancam pidana kurungan paling lama 3 (tiga) bulan atau denda paling banyak Rp. 10.000.000,00 (sepuluh juta rupiah). 
26. Perda Nomor 10 Tahun 2001 tentang Pemberantasan Pelacuran Kabupaten Pasuruan.

27. Perda Nomor 5 Tahun 2005 tentang Pemberantasan Pelacuran di Kabupaten Probolinggo. ${ }^{24}$

28. Perda Nomor 6 Tahun 2001 tentang Pemberantasan Pelacuran Kabupaten Bandung.

29. Perda Nomor 5 tahun 2007 tentang Larangan Pelacuran di Kabupaten Bantul. ${ }^{25}$

30. Perda Nomor 3 tahun 2002 tentang Larangan Tempat Maksiat Kabupaten Sumenep.

31. Perda Nomor 10 Tahun 2002 tentang Perubahan Keempat atas Peraturan Daerah Kabupaten Daerah Tingkat II Bekasi Nomor 17/ Hk-Pd/Tb.013.1/VIII/1984 Tentang Larangan Perbuatan Tuna Susila Kabupaten Bekasi. ${ }^{26}$

\section{Perda Nomor 21 Tahun 2003 tentang Perubahan Pertama atas Peraturan Daerah Kabupaten Daerah Tingkat II Cilacap Nomor 13}

${ }^{24}$ Pasal 2, dalam daerah siapapun dilarang berada ditempat umum atau dimana saja yang dapat dilihat oleh umum, membujuk dan memikat orang lain dengan kata-kata, isyarat-isyarat, tanda-tanda atau dengan cara lain untuk melakukan perbuatan-perbuatan zina atau cabul. Pasal 3 (1), barang siapa yang tingkah lakunya menimbulkan persangkaan bahwa ia itu seorang pelacur, dilarang tinggal dimuka umum. Pasal 10 (1), pelanggaran terhadap ketentuan-ketentuan Pasal 2, 3 ayat (3) dan Pasal 7 dalam Peraturan Daerah ini, diancam pidana kurungan paling lama 3 (tiga) bulan dan atau denda paling banyak Rp. 5.000.000,- (lima juta rupiah).

${ }^{25}$ Pengadilan Negeri Bantul pada tanggal 09 Nopember 2012, menjatuhkan denda kepada Sugiyanto dan Tri Haryati sebagai pelaku prostitusi yang masing-masing didenda Rp. 299.000,atau apabila tidak ingin membayar diganti dengan pidana kurungan selama 3 hari. Hukuman yang diberikan ini sangat ringan, tidak sesuai dengan ketentuan Pasal 8 ayat (1) Perda Kabupaten Bantul Nomor 5 Tahun 2007 tentang Larangan Melakukan Praktik Prostitusi di Kabupaten Bantul.Pasal 3(1),setiap orang dilarang melakukan pelacuran di wilayah Daerah;(2) setiap orang dilarang menjadi mucikari di wilayah Daerah.Pasal 4,setiap orang atau badan hukum dilarang menyediakan bangunan untuk dipergunakan melakukan pelacuran di Daerah.Pasal 5,setiap orang atau masyarakat dilarang melindungi kegiatan pelacuran di seluruh wilayah Daerah.Pasal 6,kegiatan usaha yang terbukti diikuti kegiatan pelacuran, aparat Pemerintah Daerah berwenang untuk melakukan penutupan.Pasal 8(1),setiap orang yang melanggar ketentuan sebagaimana dimaksud Pasal 3 dan/atau Pasal 4 dan atau Pasal 5, diancam pidana kurungan paling lama 3 (tiga) bulan atau denda paling banyak Rp.10.000.000,00 (sepuluh juta rupiah);(2) tidak pidana sebagaimana dimaksud ayat (1) pelanggaran.

${ }^{26}$ Pasal 4 (1), pidana kurungan selama-lamanya 3 (tiga) bulan atau denda sebanyakbanyaknya Rp.5.000.000,- (lima juta rupiah). 
Tahun 1989 Tentang Pemberantasan Pelacuran Kabupaten Cilacap. ${ }^{27}$

33. Perda Nomor 6 Tahun 2000 tentang Anti Perbuatan Maksiat Kabupaten Garut. ${ }^{28}$

34. Perda Nomor 4 Tahun 2001 tentang Perubahan Pertama Peraturan Daerah Kabupaten Tingkat II Indramayu Nomor 7 Tahun 1999 tentang Prostitusi Kabupaten Indramayu. ${ }^{29}$

35. Perda Nomor 10 Tahun 2003 tentang Pencegahan Maksiat Provinsi Gorontalo.

36. Perda Nomor 14 Tahun 2009 tentang Prostitusi Kabupaten Majalengka.

37. Perda Nomor 28 tahun 2000 tentang Perubahan pertama Peraturan Daerah Nomor 1 tahun 2000 tentang Pemberantasan Pelacuran Kabupaten Tasikmalaya.

38. Perda Nomor 14 Tahun 2003 tentang Khalwat (Mesum) Propinsi Daerah Istimewa Aceh.

39. Perda Nomor 6 tahun 2009 tentang Perubahan Peraturan Daerah Kabupaten Malinau Nomor Tentang 14 tahun 2003 Tentang Tuna Susila Kabupaten Malinau. ${ }^{30}$

${ }^{27}$ Pasal 8, pidana kurungan paling singkat 7 (tujuh) hari, dan paling lama 3 (tiga) bulan dan atau denda serendah-rendahnya Rp. 2.500.000,- (dua juta lima ratus ribu rupiah), dan setinggi-tingginya Rp. 5.000.000;- (lima juta rupiah).

${ }^{28}$ Pasal 4 (1), setiap orang dilarang menyediakan diri baik sendiri maupun bersama-sama secara terbuka maupun tersembunyi melakukan tindakan pelacuran. Pasal 22, pidana kurungan paling lama 3 (tiga) bulan atau denda paling banyak Rp. 50.000.000,00 (lima puluh juta rupiah).

${ }^{29}$ Pasal 5, siapapun di jalan umum atau di tempat yang kelihatan dari jalan umum atau di tempat dimana umum dapat masuk dilarang dengan perkataan, isyarat, tanda atau cara lain membujuk atau memaksa orang lain untuk melakukan perbuatan prostitusi. Pasal 6,siapapun yang kelakuannya/tingkah lakunya dapat menimbulkan dugaan bahwa ia pelacur dilarang ada di jalan-jalan umum, di lapangan-lapangan, di rumah penginapan, losmen, hotel, asrama, rumah penduduk/kontrakan, warung-warung minum, tempat hiburan, di gedung tempat tontonan, disudut-sudut jalan atau lorong-lorong, berhenti atau berjalan kaki atau berkendaraan bergerak kian kemari. Pasal 9 (1), hukuman kurungan selama-lamanya 6 (enam) bulan atau denda sebanyakbanyaknya Rp. 5.000.000,- (lima juta rupiah).

${ }^{30}$ Pasal 2 (1), setiap orang atau kelompok orang dilarang melakukan atau menyediakan orang dan atau tempat untuk perbuatan tuna susila diseluruh wilayah Daerah; (2) Setiap Badan dilarang mengusahakan dan atau menyediakan orang dan atau tempat-tempat untuk melakukan perbuatan tuna susila. Pasal 6, barang siapa yang melanggar ketentuan dalam Pasal 2 Ayat (1) Peraturan Daerah ini diancam pidana kurungan selama-lamanya 3 (tiga) bulan atau denda sebanyak-banyaknya Rp. 5.000.000.- (lima juta rupiah) kecuali ditentukan lain dalam peraturan perundangan-undangan yang berlaku." 
40. Perda Nomor 2 Tahun 2014 tentang Pemberantasan Pelacuran dan Perbuatan Asusila Kota Jambi. ${ }^{31}$

41. Perda Nomor 10 Tahun 2008 tentang Penanggulangan Pelacuran di Kabupaten Kendal. ${ }^{32}$

\section{Perda Nomor 7 Tahun 2006 tentang Larangan Pelacuran Kabupaten Lampung Utara. ${ }^{33}$}

\section{Peraturan Daerah (Perda) Kabupaten Kebumen Nomor 6 tahun 1973 Lembaran Dati I Jateng Seri C 117 tentang Larangan Melakukan Pelacuran di Tempat Umum. ${ }^{34}$}

Pengaturan prostitusi di dalam peraturan-peraturan daerah tersebut secara implisit mengatur bagaimana pelaku prostitusi baik sebagai pekerja

${ }^{31}$ Pasal 2, setiap orang dilarang: a. menawarkan diri, mengajak orang lain baik secara langsung dan/atau tidak langsung dengan menggunakan media informasi untuk melakukan pelacuran; b. berkeliaran di jalan atau di tempat-tempat umum dengan tujuan melacurkan diri; c. memanggil atau memesan pelacur baik secara langsung maupun tidak langsung dengan menggunakan media informasi dengan maksud untuk melakukan pelacuran; d. melakukan pelacuran. Pasal 16, dipidana dengan pidana kurungan paling lama 3 (tiga) bulan atau denda paling banyak Rp. 25.000.000,- (dua puluh lima juta rupiah).

${ }^{32}$ Pasal 3, setiap orang di Daerah baik sendiri-sendiri ataupun bersama-sama dilarang membujuk/merayu, mempengaruhi, memikat, mengajak, dan/atau memaksa orang lain dengan kata-kata, isyarat, tanda, dan/atau perbuatan lainnya yang dapat mengakibatkan perbuatanpelacuran, pidana kurungan paling lama 3 (tiga) bulan dan/atau denda paling tinggi Rp 50.000.000,00 (lima puluh juta rupiah).

${ }^{33}$ Pasal 3, setiap orang dilarang menyuruh melakukan, membujuk atau memaksa orang lain baik dengan cara perkataan, isyarat, tanda atau cara lain sehingga tertarik untuk melakukan pelacuran. Pasal 9 (1), pidana kurungan paling lama 6 (enam) bulan atau ; b. denda sebanyakbanyaknya Rp. 5.000.000,00,- (lima juta rupiah).

${ }_{34}$ Perda ini dipakai untuk menjerat Siti Bariyah. Pasal yang dipergunakan adalah Pasal 2 jo Pasal 8, Terdakwa telah dinyatakan bersalah melakukan tindak pidana seperti tercantum dalam putusan Pengadilan Negeri tersebut yang amar lengkapnya berbunyi sebagai berikut: 1.Menyatakan Terdakwa Siti Bariyah terbukti sah dan meyakinkan, bersalah melakukan tindak pidana pelacuran ditempat umum; 2. Menghukum oleh karena itu, Terdakwa dengan hukuman kurungan selama 4 (empat) hari; dan 3. Membebani Terdakwa membayar ongkos perkara sebesar Rp.500,- (lima ratus rupiah). Putusan Pengadilan Negeri Kebumen dalam pemeriksaan pada tingkat banding telah dibatalkan oleh Pengadilan Tinggi Jawa Tengah di Semarang dengan putusannya tanggal 4 Maret 2002 Nomor: 32/PID/2002/PT.SMG., yang amar lengkapnya berbunyi sebagai berikut: 1 . Menerima permohonan banding dari Terdakwa; 2. Membatalkan putusan Pengadilan Negeri Kebumen tanggal 14 Januari 2002 Nomor 04/Pid.C/2002/PN.Kbm., yang dimohonkan banding; dan Dengan Mengadili Sendiri: 1. Memerintahkan kepada Pengadilan Negeri Kebumen untuk mengembalikan berkas perkara beserta putusannya ke Penyidik agar perkara diajukan kembali dengan acara pemeriksaan singkat; 2.Membebankan biaya perkara dalam kedua tingkat pemeriksaan yang dalam tingkat banding dibebankan kepada Negara. Putusan Mahkamah Agung menguatkan putusan Pengadilan Negeri Kebumen dengan ditolaknya kasasi. 
seks, germo, mucikari, dan pemilik tempat bordil. Pengaturan ini menjadi landasan bagi penegak hukum untuk menjerat pelaku. Pelaku prostitusi dapat dikenai pidana walaupun bentuk pidananya yang ditetapkan adalah pidana yang bersifat pelanggaran.

Sifat pelanggaran yang dikenakan kepada pelaku prostitusi berdampak pada lemahnya penerapan peraturan daerah. Efek penjera yang terkandung di dalamnya tidak efektif mencegah dan menanggulangi prostitusi. Hal ini ditambah dengan tidak tegasnya stakeholders dalam menegakkan peraturan daerah. Kelemahan ini yang menjadi sumber malapetaka makin maraknya prostitusi di tengah masyarakat.

\section{Unsur Penjera Sanksi Pidana dalam Peraturan-Peraturan Daerah Terkait Prostitusi}

Kaidah hukum Islam mengenal konsep ijtihad sebagai salah satu metode yang dihadirkan dalam rangka menginterpretasikan teks-teks hukum sehingga mampu merespon kebutuhan dan tuntutan masyarakat, antara lain terkait dengan munculnya perbuatan-perbuatan berbahaya (kejahatan-kejahatan). Sebagian fuqahâ menggunakan kata jinâyah untuk perbuatan berbahaya yang berkaitan dengan jiwa atau anggota badan, seperti membunuh, melukai, menggugurkan kandungan dan lain sebagainya. Jinâyah merupakan suatu tindakan yang dilarang oleh syara' karena dapat menimbulkan bahaya bagi jiwa, harta, keturunan, dan akal (intelegensi). Dengan demikian, istilah fiqh jinâyah sama dengan hukum pidana. Pengertian jinâyah dalam bahasa Indonesia sering disebut dan dipersamakan dengan istilah Peristiwa Pidana, ${ }^{35}$ Delik, atau Tindak Pidana.

Klasifikasi jarîmah (tindak pidana) dalam Islam, jika dilihat dari aspek berat ringannya hukuman maka ada 3 (tiga) jenis jarîmah. ${ }^{36}$

${ }^{35}$ Sayyid Sabiq, Fiqh al-Sunnah, vol. Jilid 2 (Bayrût: Dâr al-Fikr, 1992).

${ }^{36}$ Laila Mulasari, "Kebijakan Formulasi Tentang Tindak Pidana Kesusilaan di Dunia Maya dalam Perspektif Hukum Islam", Masalah-Masalah Hukum, 41, no. 1 (2012): h.102. Herlita Eryke, "Cyberporn" Jurnal Ilmiah K U T E I, Sepember (2010), h. 35-42. Mohammad Haidar Ali, "Cyber Crime Menurut Undang-Undang Republik Indonesia Nomor 11 Tahun 2008 Tentang ITE (Perspektif Hukum Pidana Islam)”, Tesis, UIN Alauddin Makassar, 2012. Dwi Haryadi, "Kebijakan Formulasi Hukum Pidana Terhadap Penanggulangan Cyberporn dalam Rangka Pembaharuan Hukum Pidana di Indonesia”, Tesis, Universitas Diponegoro, 2007. 
Pertama, jarîmah hudûd. Ini merupakan perbuatan melanggar hukum yang jenis dan ancaman hukumannya ditentukan oleh nas yaitu berupa hukuman Had (hak Allah). Para ulama sepakat bahwa yang termasuk kategori jarîmah hudîd ada 7 (tujuh), yaitu zina, qadzaf (menuduh zina), pencurian, perampokan atau penyamunan (hirabah), pemberontakan (al-baghy), minum-minuman keras dan riddah (murtad). Kedua, jarîmah qishâs diyât yakni suatu perbuatan yang diancam dengan hukuman qishâs dan diyât. Adapun yang termasuk kategori jarîmah qishâs diyât ini adalah pembunuhan dengan sengaja (al-qatl al-'amd), pembunuhan semi sengaja (al-qatl sibh al-'amd), pembunuhan keliru (al-qatl al-khata), penganiayaan dengan sengaja (al-jarh al-'amd), dan penganiayaan tanpa kesengajaan (al-jarh al-khata'). Ketiga, jarîmah ta'zîr ini merupakan suatu bentuk jarimah yang diancam dengan hukuman ta'zîr yaitu hukuman selain had dan qishâs diyât.

Prostitusi adalah penyediaan layanan seksual yang dilakukan oleh laki-laki atau perempuan untuk mendapatkan uang atau kepuasan. Unsur "layanan seksual" dalam definisi prostitusi mengandung arti hubungan badan antara laki-laki dan perempuan yang tidak terikat dengan hubungan pernikahan. Unsur ini sama dengan unsur yang terkandung dalam unsur zina dalam hukum Islam sehingga prostitusi dapat dijerat dengan jinâyah hudûd yang dipakai untuk menjerat pelaku zina.

Hukuman dalam istilah Arab sering disebut uqûbah, yaitu bentuk balasan bagi seseorang yang atas perbuatannya melanggar ketentuan syara' yang ditetapkan oleh Allah dan Rasul-Nya untuk kemaslahatan manusia. Tujuan pemidanaan dalam syariat Islam yakni sebagai pembalasan perbuatan jahat, pencegahan secara umum (general prevention) dan pencegahan secara khusus (special prevention) serta perlindungan terhadap hak-hak korban. Pemidanaan dimaksudkan untuk mendatangkan kemaslahatan umat dan mencegah kezaliman atau kemudharataan. Hal ini sejalan dengan pendapat Ahmad Hanafi yang menyatakan bahwa tujuan pokok dalam penjatuhan hukuman dalam syariat Islam ialah pencegahan (al-raddu wa al-zajru) dan pengajaran $^{37}$ serta pendidikan (al-ishlâh wa al-tahdhib).

${ }^{37}$ Laila Mulasari, "Kebijakan Formulasi Tentang Tindak Pidana Kesusilaan di Dunia Maya dalam Perspektif Hukum Islam”, Masalah-Masalah Hukum, 41, no. 1 (2012). 
Sebagian umat Islam, khususnya mereka yang terlibat dalam politik, menuntut pemberlakuan syariat Islam dengan memperlihatkan asumsi bahwa reformasi dalam kehidupan umat Islam dapat dilakukan dengan pendekatan hukum, institusi, dan instrumen negara. Syariat dalam hal ini dipersepsikan pada nuansa yang berbasis negara dan perangkatperangkatnya. Oleh karena itu, syariat Islam secara legal formal dalam konstitusi diupayakan dapat tercantum. Kelompok-kelompok yang ingin menerapkan syariat Islam seringkali menekankan hudûd sebagai unsur pokok dalam penerapan syariat. Selama hudûd belum diterapkan, penerapan syariat Islam dipandang tidak lebih dari basa-basi. ${ }^{38}$ Hudûd menjadi garis pemisah yang nyata dan tegas antara kelompok yang menginginkan syariat Islam dan para penentang. Bagi kelompok yang menentang penerapan syariat Islam, hudûd juga menjadi target utama. Sebagai isu kontroversial antara kelompok yang pro dan yang kontra, hudûd lebih membedakan dan menimbulkan polarisasi daripada hukum keluarga seperti nikah, talak, cerai, dan rujuk, demikian juga yang berkaitan dengan formalisasi zakat, wakaf, bank syariah, dan haji. Untuk itu, pembaruan hukum pidana secara aplikatif terhadap syariat Islam perlu dilakukan untuk meminimalisir visted interest di kalangan yang pro dan yang kontra penerapan syariat Islam. Sebagai langkah rekonstruksi terhadap masalah hudûd, misalnya, adalah hukuman rajam bagi pelaku zina.

Rajam merupakan hukuman yang diakui oleh seluruh fuqahầ kecuali sekelompok azâriqah dari kelompok khawârij. Mereka tidak menerima hadis-hadis jika tidak memenuhi syarat mutawâtir. Menurut mereka, hukuman bagi mubshan dan yang bukan mubshan adalah jilid. Mereka

${ }^{38}$ Berbagai aspek hukum Islam yang ada, hudûd memang menjadi primadona, bahkan dibandingkan dengan kejahatan-kejahatan yang lain. Sebagai contoh, dari tiga kategori kejahatan (hudûd, qishâsh, dan ta'zîr), kejahatan qishâsh tidak banyak dibicarakan berkaitan dengan penerapan syariat Islam. Seperti diketahui, kejahatan-kejahatan qishâsh mencakup pembunuhan dengan sengaja, pembunuhan yang terjadi karena salah sasaran, pembunuhan yang tidak disengaja, dan kejahatan yang disengaja dengan person baik yang menimbulkan cidera atau cacat. Hukuman untuk kejahatan semacam ini adalah retalisasi dan kompensasi (diyah). Demikian juga kategori kejahatan ta'zîr tidak banyak mengandung kontroversi karena memang dalam sejarah ta'zîr diperkenalkan belakangan dan menjadi wadah bagi jenis-jenis kejahatan kategori sisa dari yang ada di dalam hudûd, dan qishâsh. 
menyandarkan hukuman itu kepada Alquran surah al-Nîr ayat 2.39 Pendapat ini sejalan dengan pandangan al-Na'im, hanya argumennya yang berbeda. Al-Na'im memberi penekanan, jilid adalah hukuman hadd yang didasarkan pada Alquran, sedangkan rajam yang berdasarkan alSunnah ${ }^{40}$ berlaku dalam situasi tertentu, ${ }^{41}$ tidak totalitas. Tampaknya hukuman rajam bagi pelaku zina muhshan di dalam Alquran tidak ada, yang ada hanya dalam hadis. Penerapan rajam dalam aspek penjeraan tidak tercermin, karena peluang hidup bagi pelakunya sangat mungkin tidak ada. Hukuman hadd sebagai hak Allah, inti penekanannya adalah kemaslahatan umat dan penyadaran. Jika hukuman jilid memberi penyadaran, kemaslahatan umat tidak terganggu. Sanksi hukum yang bersifat kondisional ini dapat dikembangkan berupa hukuman penjara atau sanksi hukum lain yang mengarah pada mashlahah dan penyadaran. Paradigma di atas sejalan dengan pemikiran hukum pidana Islam kontemporer. Hukuman dalam konteks riil lebih ditekankan pada aspek zawâjir daripada aspek jawâbir sebagai maqâshid atau illah hukum. Artinya, hukuman yang dilakukan ditekankan kepada yang bersalah agar jera dan tidak akan mengulangi tindak pidana. Dengan demikian, hukuman tidak terikat dan terpaku pada apa yang tertera dalam nash. Atas dasar ini, pelaku tindak pidana bisa saja dihukum dengan hukuman selain yang tertera dalam nash, yang penting hukuman itu diharapkan dapat membuat pelakunya jera, tidak akan mengulangi lagi perbuatan yang serupa dan membuat orang mempunya niat serupa mengurungkan niatnya. ${ }^{42}$ Dalam konteks

${ }^{39}$ Muhammad Sa'îd al-'Ashmawî, Syarî́ah: Kodifikasi Hukum Islam (Wacana Islam Liberal: Pemikiran Islam Kontemporer tentang Isu-isu Global, ), ed. oleh Charles Kursman (editor), trans. oleh Bahrul Ulum (pent.) (Jakarta: Paramadina, 2001).

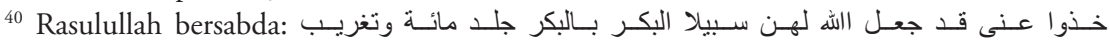
(Ambillah dariku, Allah telah memberikan jalan kepada para wanita yang berzina. Bujangan yang berzina dengan bujangan dijilid seratus kali dan diasingkan selama satu tahun. Duda yang berzina dengan janda dijilid seratus kali dan dirajam dengan batu). Lihat Abû al-Hasan Muslim bin Hajjâj al-Qushayrî al-Naysâ bûrî, Shahîh Muslim, (Bayrût: Dâr al-Kutub al-'Ilmiyyah, 1992), Jilid 3,h. 1316. Lihat juga Abû 'Abd. Allâh Muhammad bin Yazîd al-Qazwînî, Sunan Ibn Mâjah,(Bayrût: Dâr al-Kutub al-'Ilmiyyah. t.t.), Juz 2, h. 853; Abû Dâwud Sulaymân bin Ash'ath al-Sijistâni, Sunan Abî Dâwud,(Bayrût: Dâr al-Fikr, 1994), Juz 2, h. 348.

${ }^{41}$ Abdullahi Ahmed al-Na'im, Toward an Islamic Reformation: Civil Liberties, Human Rights, and International Law (New York: Syracuse University Press, 1990).

${ }^{42}$ Ibrahim Hosen dan Muhammad Wahyuni Nafis, et al., "Beberapa Catatan tentang 
ini, pendekatan ta'aqqulî didahulukan daripada pendekatan ta'abbudi. Dengan cara berpikir seperti ini, illat al-hukm dan hikmat al-tashrî́ dapat dicerna oleh penalaran rasional yang dapat diterima oleh masyarakat.

Elastisitas hukum dengan tanpa melepaskan pendekatan normativisme hukum tersebut lebih sejalan daripada dogmatisme hukum yang tidak boleh ditawar-tawar. Oleh karena itu, sangat proporsional jika rajam yang berdasarkan hadis hanya bersifat kondisional. Rajam yang terjadi pada masa Islam awal merupakan hukuman yang didasarkan pada kebijakan tertentu.

Untuk itu, sangat bijak dan lebih mengandung keadilan jika hukuman zina tidak terlalu diberatkan. Kesempatan bagi pelakunya untuk memperbaiki diri sangat diperlukan, sehingga dia menjadi orang yang berguna bagi masyarakatnya kelak. Berdasarkan nilai mashlahah dan keadilan yang dijadikan ukuran dalam menentukan hukum, maka hal yang sangat urgen adalah kesesuaian hukum dengan masyarakat. Artinya, jika terdapat hukuman selain rajam atau jilid dan hukuman itu diterima oleh masyarakat serta menjadi standard untuk ukuran mashlahah dan adil, maka pemberlakuan hukum itu dapat diterima. Meskipun demikian, langkah itu harus memperhatikan berbagai aspek tujuan. Dalam hal ini, tujuan hukum pidana itu untuk memenuhi rasa keadilan, pembalasan, dan pencegahan agar tidak melakukan pelanggaran lagi yang dapat ditiru oleh masyarakat yang lain. Di samping itu, pemidanaan ini dipakai sebagai langkah untuk mendidik dan membantu terpidana supaya hidup tenteram dan diterima oleh masyarakat seperti sebelum dia melakukan pelanggaran.

Keterangan di atas tidak berarti menafikan konsepsi yang menetapkan hukum rajam atau jilid sebagai satu-satunya hukuman bagi pelaku zina. Pemberlakuan hukuman ini dilakukan jika kondisi masyarakat menerima dan tindak pidana terjadi dalam keadaan normal. Jika tidak, maka harus dicari alternatif hukum yang akseptabel dan mengantarkan pada penjeraan. Dengan demikian, akal pikiran dapat menyusun ketentuan- 
ketentuan baru, meskipun diktum-diktum hukum spesifik Alquran terabaikan, asal sejalan atau tidak bertentangan dengan ajaran pokok dimana Alquran diturunkan. Hukum pidana budûd yang bermuara pada relativitas sanksi hukum sebagian besar pada dasarnya telah diatur dalam hukum nasional. Dengan demikian, ideal moral Alquran dan al-Sunnah telah diimplementasikan dalam hukum pidana nasional.

Secara umum, penerapan hukum pidana dalam syariat diorientasikan pada prinsip larangan, bukan sanksi. Untuk itu, langkah mamasukkan hukum pidana Islam tetap merujuk pada ideal moral, bukan legal spesifik. Dalam konteks tersebut, Perda syariat tentang perzinaan di beberapa daerah mendapat legitimasi. Meskipun demikian, Perda itu tidak berlabelkan Islam, ukurannya adalah pandangan secara umum seperti Perda anti prostitusi yang semua komponen umat beragama melarangnya. Dalam hal ini, Perda tidak bertentangan dengan hak asasi manusia dan mengganggu kepentingan orang lain. Perda syariat mengakomodasi berbagai kepentingan umat, tetap dalam bingkai NKRI, dan berorientasi pada ideologi Pancasila. Untuk itu, sanksi Perda anti pelacuran tidak secara normatif sesuai dengan teks sanksi yang tertuang dalam Alquran, tetapi secara moral sanksi dapat diberikan sesuai kesepakatan daerah dengan merujuk pada ideal moral dalam Alquran dan al-Sunnah.

\section{Penutup}

Berdasarkan uraian di atas, penulis menghasilkan memberikan kesimpulan. Pertama, kedudukan peraturan daerah terkait larangan prostitusi di Indonesia dalam tata urutan peraturan perundang-undangan sudah kuat apabila diuji dengan Undang-Undang Nomor 12 Tahun 2011 tentang Pembuatan Peraturan Perundang-undangan dan Undang-Undang Nomor 23 tahun 2014 tentang Pemerintah Daerah. Apabila diuji dengan undang-undang lain, maka ditemukan pertentangan.

Kedua, sanksi pidana dalam peraturan daerah terkait larangan prostitusi sesuai dengan hukum pidana Islam. Dalam pidana Islam untuk pemberantasan dan penanggulangan prostitusi dilakukan dengan menekankan konteks riil pada aspek zawâjir daripada aspek jawâbir sebagai maqâshid atau illah hukum. Artinya, hukuman yang dilakukan 
ditekankan kepada yang bersalah agar jera dan tidak akan mengulangi tindak pidana. Dengan demikian, hukuman tidak terikat dan terpaku pada apa yang tertera dalam nash. Atas dasar ini, pelaku tindak pidana bisa saja dihukum dengan hukuman selain yang tertera dalam nash, yang penting hukuman itu diharapkan dapat membuat pelakunya jera, tidak akan mengulangi lagi perbuatan yang serupa dan membuat orang mempunya niat serupa mengurungkan niatnya. Dengan demikian penetapan sanksi pidana Islam terhadap pelaku prostitusi tidak mesti dilakukan dengan penjilidan atau rajam yang tidak memberikan orang berubah untuk berbuat baik, tetapi diterapkan penjara atau denda selama mengandung unsur penjera.

Ketiga, sanksi pidana bagi pelaku praktik prostitusi dalam peraturanperaturan daerah terkait prostitusi di Indonesia mengandung unsur penjera. Namun unsur penjera dalam tidaklah kuat mengingat peraturan daerah menetapkan prostitusi dengan delik pelanggaran yang tidak boleh mendenda melebihi Rp. 50.000.000,- (lima puluh juta rupiah), dan tidak boleh mengurung lebih dari 6 (enam bulan). Hal ini terkait dengan teknis pembentukan peraturan daerah harus merujuk pada Pasal 15 ayat (2) Undang-Undang Nomor 12 Tahun 2011 tentang Pembentukan Peraturan Perundang-undangan.

Keempat, kebijakan yang dapat diterapkan di Indonesia untuk mencegah dan menanggulangi prostitusi adalah kebijakan abolisi. Abolisi merupakan kebijakan penghapusan prostitusi di muka bumi. Upaya ini dilakukan dengan langkah komprehensif dengan penegakan hukum dan pemberitaan di media massa atau online bagi pelaku prostitusi. Dengan pemberitaan ini, maka dipastikan praktik prostitusi akan hilang.

\section{Pustaka Acuan}

'Ashmawî, Muhammad Sa îd al-. Syarî‘ah: Kodifikasi Hukum Islam (Wacana Islam Liberal: Pemikiran Islam Kontemporer tentang Isu-isu Global), ed. oleh Charles Kursman (editor), trans. oleh Bahrul Ulum (pent.) Jakarta: Paramadina, 2001.

Ambarwati, Vivi. "Fenomena Prostitusi di Pantai Samas Bantul Yogyakarta.” DIMENSIA 6, no. 1 (2012). 
Amalia, Astry Sandra. "Dampak Lokalisasi Pekerja Seks Komersial (PSK) Terhadap Masyarakat Sekitar (Studi Kasus di Jalan Soekarno-Hatta Km. 10 Desa Purwajaya Kabupaten Kutai Kartanegara).” eJournal Administrasi Negara 1 (2013).

AS, A. Sunarto. "Kyai dan Prostitusi: Pendekatan Dakwah KH. Muhammad Khoiron Suaeb di Lokalisasi Kota Surabaya." Jurnal Komunikasi Islam 3, no. 2 (2012).

Ali, Mohammad Haidar. "Cyber Crime Menurut Undang-Undang Republik Indonesia Nomor 11 Tahun 2008 Tentang ITE (Perspektif Hukum Pidana Islam)”. Tesis. UIN Alauddin Makassar, 2012.

Bukhârî, Abû Abdillah Muhammad bin Ismâ'îl al-. Sahîh al-Bukhârî, vol. juz 8. Semarang: Toha Putra, tt.

Departemen Kesehatan RI, 2012.

Editor, "100 Countries and Their Prostitution Policies," 12 Januari 2017, http://prostitution. $\neg$ pro $\neg$ con.org/view.resource. php?resourceID=000772.

Eryke, Herlita. "Cyberporn”. Jurnal Ilmiah K U T E I, September (2010), $35-42$.

Erianjoni, Erianjoni, and Ikhwan Ikhwan. "Pola dan Jaringan Prostitusi Terselubung di Kota Padang." Humanus 11, no. 2 (2012): 112-118.

Faidah, Mutimmatul. "Pusaran Ekonomi di Balik Bisnis Prostitusi di Lokalisasi Dolly-Jarak Surabaya." Lentera 10, no. 1 (2014): 17-29.

Fathonah, Rini. "Analisis Terhadap Faktor Penyebab Prostitusi pada Anak.” JURNAL POENALE 3, no. 4 (2016).

Hajjâj, Abu al-Husain Muslim bin al-. Sahîh Muslim, vol. juz IV. Bayrût: Dâr Ihyâ' al-âth al-'Arabî, tt.

Hosen, Ibrahim dan Muhammad Wahyuni Nafis, et al. "Beberapa Catatan tentang Reaktualisasi Hukum Islam," dalam "Kontekstualisasi Ajaran Islam”. Jakarta: Ikatan Persaudaraan Haji Indonesia Bekerjasama dengan Yayasan Wakaf Paramadina, 1995.

Haryadi, Dwi. "Kebijakan Formulasi Hukum Pidana Terhadap Penanggulangan Cyberporn dalam Rangka Pembaharuan Hukum Pidana di Indonesia”. Tesis. Universitas Diponegoro, 2007. 
Issabela, Nida, and Wiwin Hendriani. "Resiliensi pada Keluarga yang Tinggal di Lingkungan Lokalisasi Dupak, Bangunsari.” Jurnal Insan Media Psikologi 12, no. 3 (2012).

Irwansyah, Lutfi. "Kemiskinan, Keluarga dan Prostitusi pada Remaja." Seminar Asean 2nd Psychology \& Humanity. Psychology Forum UMM, 2016.

Jamal, Cemi Fitriani. "Politik Prostitusi Kota Surabaya (Studi Deskriptif: Eksistensi Dolly).” Junal Politik Muda, Universitas Airlangga 2, no. 1 (2013).

Kartono, Kartini. Patologi Sosial. Jakarta: PT. Raja Grafindo Persada, 1997. Lang, Lanny Carolina Maria. "Perlindungan Hukum Terhadap Hak Anak Korban Praktik Prostitusi dari Wisatawan.” Lex Et Societatis 2, no. 1 (2014).

Masland, Robert P. dan dan Jr. David Estridge, Apa yang Ingin Diketahui Remaja Tentang Seks. Jakarta: Bumi Aksara, 1987.

Mulasari, Laila. "Kebijakan Formulasi Tentang Tindak Pidana Kesusilaan di Dunia Maya dalam Perspektif Hukum Islam”. Masalah-Masalah Hukum, 41, no. 1 (2012): 102.

Naysâbûrî, Abû al-Hasan Muslim bin Hajjâj al-Qushayrî al-. Shahîh Muslim. Bayrût: Dâr al-Kutub al-'Ilmiyyah, 1992.

Nitimiharjo, Carolina. "Peran Sistem Kepribadian dan Lingkungan dalam Perilaku Prostitusi." Jurnal Psikologi 5, no. 1 (2000): 56-63.

Na'im, Abdullahi Ahmed al-. Toward an Islamic Reformation: Civil Liberties, Human Rights, and International Law. New York: Syracuse University Press, 1990.

Paramita, Astridya, Widjiartini Widjiartini, and Paiman Soeparmanto. "Pelayanan Kesehatan Reproduksi Remaja oleh Puskesmas yang di Wilayah Kerjanya Terdapat Lokasi Prostitusi (Studi di Kota Malang dan Kabupaten Tulungagung)." Buletin Penelitian Sistem Kesehatan 9, no. 3 Jul (2006).

Poerdarmita, W.J.S. Kamus Umum Bahasa Indonesia. Jakarta: PN Balai Pustaka, 1984.

Pebriana, Cindika Eka, dkk. "Analisis Yuridis Kebijakan Hukum Pidana 
dalam Menanggulangi Tindak Pidana Prostitusi Melalui Media Online Sebagai Kejahatan Mayantara (Studi Putusan No. 228/ PID. B/2015. PN. PGP).” Jurnal Diponegoro Law Review, Volume5, Nomor 3 (2016).

Pradana, Arya Mahardhika. "Tinjauan Hukum Pidana Terhadap Prostitusi dan Pertanggungjawaban Pidana Para Pihak yang Terlibat dalam Prostitusi." Jurnal Hukum \& Pembangunan 45, no. 2 (2015): 276-307.

Qazwînî, Abû 'Abd. Allâh Muhammad bin Yazîd al-. Sunan Ibn Mâjah. Bayrût: Dâr al-Kutub al-'Ilmiyyah. t.t.

Sari, Melinda Novi, Madiasa Ablisar, and Rafiqoh Lubis. "Kebijakan Hukum Pidana dalam Penanggulangan Tindak Pidana Prostitusi Melalui Media Online.” Jurnal Mahupiki 1, no. 01 (2014).

Sabiq, Sayyid. Fiqh al-Sunnah. vol. Jilid 2. Bayrût: Dâr al-Fikr, 1992.

Sijistâni, Abû Dâwud Sulaymân bin Ash'ath al-. Sunan Abî Dâwud. Bayrût: Dâr al-Fikr, 1994.

Siregar, Kondar. "Model Pengaturan Hukum tentang Pencegahan Tindak Prostitusi Berbasis Masyarakat Adat Dalihan Na Tolu.” Medan: Perdana Mitra Handalan (2015).

Suryandaru, Yayan Sakti. "Hegemoni dan Reproduksi Kekuasaan dalam Perdagangan Perempuan (Trafficking) untuk Prostitusi.” Jurnal Manusia, Kebudayaan, dan Politik (2001).

Tahnh-Dam Truong, Pariwisata dan Pelacuran di Asia Tenggara, trans. oleh Moh. Arif. Jakarta: LP3ES, 1992.

Yanto, Oksidelfa. "Prostitusi Online Sebagai Kejahatan Kemanusiaan Terhadap Anak: Telaah Hukum Islam dan Hukum Positif.” AHKAM: Jurnal Ilmu Syariah 16, no. 2 (2016): 187-196.

Yahman, Soleh Amini. "Prostitusi: Antara Masalah Sosial, Ekonomi, Moral atau Etika Sosial.” Indigenous: Jurnal Ilmiah Psikologi (2007). Wicaksono, Ganang Adityo. "Deligitimasi Kebijakan Penataan Ulang Wisata Prostitusi Dolly: Studi Deskriptif Perlawanan Komunitas Dolly.” PhD diss., Universitas Airlangga, 2012. 
Wongso, Raisanta. "Kejahatan Cyber Berbasis Prostitusi Ditinjau dari Undang-Undang Nomor 11 Tahun 2008 Tentang Informatika Transaksi dan Elektronik." Lex Privatum 4, No. 4 (2016). 